\title{
Gene expression profiling of cholangiocarcinoma- derived fibroblast reveals alterations related to tumor progression and indicates periostin as a poor prognostic marker
}

Kusumawadee Utispan ${ }^{1,7}$, Peti Thuwajit ${ }^{2,7}$, Yoshimitsu Abiko ${ }^{3}$, Komgrid Charngkaew ${ }^{4}$, Anucha Paupairoj ${ }^{5,7}$, Siri Chau-in ${ }^{6,7}$, Chanitra Thuwajit ${ }^{2,7^{*}}$

\begin{abstract}
Background: Fibroblasts play important roles in several cancers. It was hypothesized that cholangiocarcinoma (CCA)-associated fibroblasts (Cfs) differ from non-tumorigenic liver fibroblasts (Lfs) in their gene expression profiles resulting in the capability to promote cancer. Periostin (PN) is a multi-functional protein and has emerged as a promising marker for tumor progression. The role of PN in CCA, however, has not yet been explored.

Results: In this study, the gene expression profile of Cfs in comparison to Lfs was performed using oligonucleotide microarrays. The common- and unique-expressed genes in Cfs and the promising roles in cancer promotion and progression were determined. PN was markedly over-expressed in Cfs confirmed by real time RT-PCR and western blot analysis. Immunohistochemistry examination of a number of patients with intrahepatic CCA showed the expression of PN solely in stromal fibroblasts, but was expressed neither in cancer cells nor immune cells. Low to no expression of PN was observed in tissues of benign liver disease and hepatocellular carcinoma. CCA patients with high levels of PN had significantly shorter survival time than those with low levels $(P=0.026)$. Multivariate analysis revealed high levels of PN $(P=0.045)$ and presence of lymph node metastasis $(P=0.002)$ as independent poor prognostic factors. The in vitro study revealed that recombinant PN induced CCA cell proliferation and invasion. Interestingly, interference RNA against integrin $\alpha_{5}$ significantly reduced the cellular response to PN-stimulated proliferation and invasion.

Conclusion: The gene expression profile of fibroblasts in CCA is apparently explored for the first time and has determined the genes involving in induction of this cancer progression. High PN can be used to distinguish CCA from other related liver diseases and is proposed as a prognostic factor of poor survival. Regulation of fibroblastderived PN in CCA proliferation and invasion may be considered as an alternative therapeutic approach.
\end{abstract}

\section{Background}

Cholangiocarcinoma (CCA) originates from biliary epithelial cells and is a unique cancer in northeastern Thailand where the prevalence of a liver fluke, Opisthorchis viverrini infection is higher than elsewhere in the country. A recent study showed a strong positive correlation of CCA incidence and the prevalence of $O$. viverrini infection [1]. In other countries, CCA has been

\footnotetext{
* Correspondence: cthuwajit@yahoo.com

2Department of Immunology, Faculty of Medicine Siriraj Hospital, Mahidol University, 2 Prannok Road, Bangkok Noi, Bangkok 10700, Thailand
}

shown to correlate with Clonorchis sinesis [2,3], and chronic biliary diseases [4]. Even though CCA is caused from the different etiologies, it is well recognized to contain an abundant fibrous stroma that is mainly composed of $\alpha$-smooth muscle actin (SMA) positive fibroblasts [5,6]. In addition, the degree of $\alpha-S M A$ expression has been shown to correlate with the survival of patients, in part, via the ability of these cancer-associated fibroblasts to induce proliferation of bile duct epithelial and cancer cells [6].

The ability of stromal fibroblasts to generate a favorable microenvironment for cancer cells leading to cancer 
development, invasion and metastasis has been summarized $[7,8]$. Mitotic substances have been produced from stromal fibroblasts to promote tumor growth in many cancers $[9,10]$. In addition, some matrix metalloproteinases which are often mentioned as proteolytic substances of the extracellular matrix (ECM) and have been reported to show increased production from cancer stromal fibroblasts. These proteolytic substances appear to help to promote cancer cell invasion and metastasis [11]. Specifically, in CCA, stromal-derived factor 1 (SDF-1) has been secreted from stromal fibroblasts into the microenvironment in which it was located at the edge of cancer masses and was proposed to play important role in induction of CCA cell invasion and metastasis [12]

To understand the roles of fibroblasts in carcinogenesis, cancer promotion and progression, gene profiling of cancer fibroblasts have been studied in many cancers [13-15]. Stromal cancer fibroblasts from breast cancer with invasion were compared with the expression profiles of fibroblasts in benign breast disorders. $H Y L$ (Csk-homologous kinase $\mathrm{CHK}$ ) involving in regulation of Src kinase, GM CSF-1 (granulocyte monocyte colony stimulating factor-1) and osteopontin were up-regulated which may result in induction of tumor growth and metastasis [13]. Among genes encoded for secreted proteins over-expressed in fibroblasts of human basal cell carcinoma [14], genes including CTSK (cathepsin K), SFRP2 (secreted frizzled-related protein 2), PDGFRL (platelet-derived growth factor receptor-like protein), and $D C N$ (decorin) were shown to be up-regulated in non-epithelial cells of breast cancer [16]. In contrast, these genes could not be detected in fibroblasts isolated from cancers of pancreas [17], and liver metastases of colon cancer [18]. Taken together, it is possible to say that differential gene expression profile of cancer fibroblasts is partly similar but actually unique for each cancer type. This supports the importance of specific recognition of the concerted performance between fibroblasts and epithelial cells in carcinogenesis and progression in different organs of origin. So it is of great value to investigate the specific gene expression profile of the CCA-derived fibroblasts to help us better understand the molecular mechanisms that fibroblasts use to promote cancer.

Periostin $(\mathrm{PN})$ is a secreted protein which was first identified in bone and implicated in regulating adhesion and differentiation of osteoblasts. The cancer biology role of $\mathrm{PN}$ has been investigated in a wide range of cancers including cell proliferation [19,20], migration [21], invasion/metastasis [22,23], and angiogenesis [23,24]. When not regarding the specific sources, either from cancer cells or fibroblasts, secreted PN has been reported to induce tumorigenic properties of epithelial cells via the activation of integrins (ITGs) receptors [21].
Even though substantial evidence has shown that cancer-associated fibroblasts are involved in tumor promotion and with the evidence that fibroblasts in CCA induce more aggressive tumorigenic properties of cancer cells [6], the role of CCA-derived fibroblasts in this cancer is yet to be determined. In the present study, fibroblasts isolated from CCA tissues or CCA-associated fibroblasts (Cfs) which were already characterized by the present group [6], were explored. The genome wide expressions of these $\mathrm{Cfs}$ were determined and compared to non-tumorigenic liver fibroblasts (Lfs). The altered expression of genes focusing on the impact of soluble products from $\mathrm{Cfs}$ on the promotion and progression of CCA was investigated. Interestingly, PN, which has never been reported in CCA was found at a high level whereas no-to-low PN was detected in non-tumor liver tissues and cancer of hepatocytes. The overexpression of PN in CCA tissues was detected solely in fibroblasts and associated with poor prognosis and short survival of the patients. The effect of PN to induce cell proliferation and invasion has been examined.

\section{Results}

\section{Gene expression analysis of $\mathrm{Cf}$ and validation by real time RT-PCR}

To reduce the genetic background of different patients, the gene expression profile of $\mathrm{Cfs}$ was compared to those of two Lfs namely Lf1 and Lf2. Lf1 was isolated from non-tumorigenic liver tissues of hepatectomized liver from the CCA patient who Cfs were originated from. The Lf2 was isolated from the other CCA patient. Genes with differential expressed levels in Cf compared to Lf1 were 3,560 for 2-fold or more up-regulation and 2,339 for 0.5 -fold or less down regulation (Fig 1A and 1B). The comparison of the Cf to Lf2 was 4,579 and 3,348 for upand down-regulation. The common differential genes which are genes altered in their expressions in Cfs when compared to both Lf1 and Lf2 (Cf/Lfs), were 1,466 for up-regulation and 495 for down-regulation. Arylacetamide deacetylase $(D A C)$, procollagen $C$ endopeptidase enhancer 2 (PCPE2), serpin peptidase inhibitor (PAI) and S100 calcium binding protein A4 (S100A4) were predominantly over-expressed at high levels in $C$ fs whereas bone morphogenic protein 2 (BMP2), matrix-remodeling associated 5 (DKFZp564I1922), bradykinin receptor B1 (BRADYB1), response gene to complement 32 (RGC32) and interleukin $24(I L-24)$ were down-regulated with a high array intensity (Table 1 ).

Most of common differentially expressed genes in Cfs play roles in controlling cellular metabolism (Table 2 and Table 3). The up-regulated genes encoded for secreted proteins were mostly classified in groups of extracellular region, proteolysis, and ECM organization/biosynthesis which took up to $11 \%$ of total genes (Table 2). Among 
A

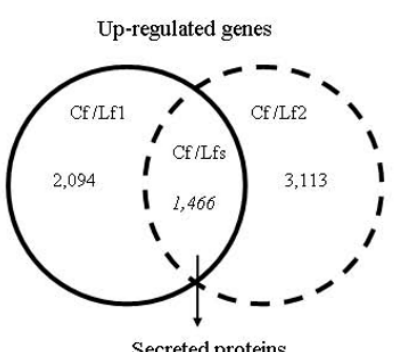

Secreted proteins

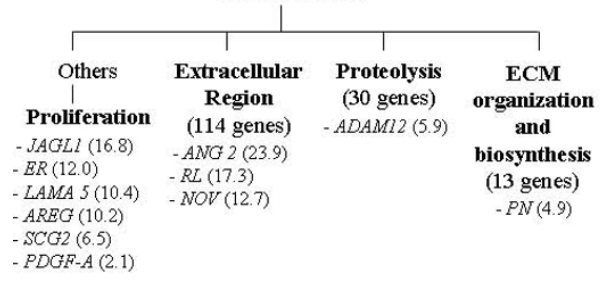

B

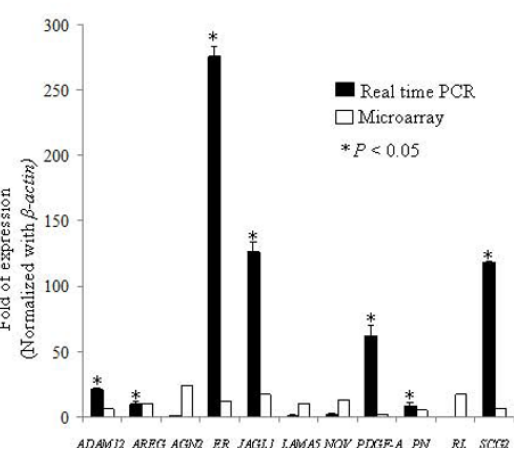

Figure 1 Genome wide expression analysis of Cf and Lfs and gene validation by real time PCR. A Vane diagram showed common upregulated genes (A) and common down-regulated genes (B) in Cf (Cf/Lfs). In this study, eleven genes encoded secreted proteins involved in induction of epithelial cell tumorigenesis including proliferation, invasion, metastasis and angiogenesis were selected from 4 main different groups of biological functions (A). The numbers in the parentheses represent folds of gene expression level of Cf over those in Lfs. The results show the comparison of gene expression levels measured by real time PCR and oligonucleotide microarray (C). Folds of expression represent fold changes of gene expression level in Cfs as compared to that in Lfs.

these genes in addition to the secreted protein encoding genes that act in cell proliferation and motility, 11 genes having several tumorigenic functions were selected for further exploration including a disintegrin and matrix metalloproteinase 12 (ADAM12), amphiregulin (AREG), angiopoietin (AGN2), epiregulin (ER), jagged1 (JAGL1), laminin alpha 5 (LAMA5), nephroblastoma over expressed $(N O V)$, platelet-derived growth factor- $\alpha$ $(P D G F-A)$, periostin $(P N)$, reelin $(R L)$, and secretogranin 2 (SCG2) (Fig 1A).

The up-regulated levels of these genes in Cfs were verified by relative quantification using real time $\mathrm{RT}$-PCR. In concordance with microarray data, real time RT-PCR results revealed that $A D A M 12, A R E G, E R$, $J A G L 1, P D G F-A, P N$ and SCG2 had significant up-regulations in Cfs compared to Lfs, but that of $N O V$ was not statistically significantly increased (Fig 1C). ANG2, $L A M A 5$, and $R L$, however, showed the opposite direction to the microarray results.

\section{Detection of PN expression in Cf and CCA tissues}

Using different biological preparation lots of $\mathrm{Cfs}$ from those used in microarray analysis, both real time RTPCR and western blot analysis confirmed that Cfs had higher expressions of $P N$ than Lfs with statistical significance (Fig 2A and 2B). The expression of $P N$ in KKU-
100, KKU-M055, KKU-M156 and KKU-M213 CCA cell lines was detected at a very low level compared to the high expression in Cfs (Fig 2C).

To check whether the increased expression of $P N$ mRNA can be found in CCA tissues, real time PCR was performed using total RNA extracted from pieces of CCA mass. Using $\beta$-actin and gapdh as the internal controls, the results showed the median of $P N$ mRNA expression was higher in CCA tissues (4.347 and 2.449 using $\beta$-actin and gapdh respectively) than in benign liver tissues (1.064 and 1.625, respectively) (Fig 2D). This increased up-regulation was not statistically significant. In addition, to achieve the aim to use a rapid method such as real time PCR in place of immunohistochemical detection of $\mathrm{PN}$ in CCA tissues, the PN mRNA level was related to the intensity of PN immunoreactivity detected by immunohistochemistry. The results indicated the positive correlation of $P N$ mRNA level and the encoding protein found in CCA tissues with statistical significance $(P=0.045)$ (Fig $2 \mathrm{E})$.

\section{Expression of PN in CCA tissues and clinicopathological relevance}

Immunohistochemistry revealed that the expression of PN was exclusively localized in fibroblasts but not cancer cells (Fig 3). Of all 52 cases, 43 cases or $83 \%$ were PN 
Table 1 List of top 20 common up-regulated genes and top 20 common down-regulated genes.

\begin{tabular}{|c|c|c|c|c|}
\hline $\begin{array}{l}\text { Gene } \\
\text { Common up-regulated genes }\end{array}$ & Abbreviation & $\begin{array}{l}\text { Intensity } \\
\text { of Cf }\end{array}$ & $\begin{array}{l}\text { Mismatch } \\
\text { binding }\end{array}$ & $\begin{array}{l}\text { Ratio } \\
\text { Cf/Lfs }\end{array}$ \\
\hline arylacetamide deacetylase (esterase) & $D A C$ & 115.92 & $P$ & 956.45 \\
\hline sparc/osteonectin (testican 3) & SPOCK3 & 16.70 & $P$ & 669.24 \\
\hline neuropeptide $Y$ receptor $Y 1$ & NPYR & 20.86 & $P$ & 416.71 \\
\hline collagen, type XIV, alpha 1 (undulin) & COL14A1 & 47.74 & $\mathrm{P}$ & 245.03 \\
\hline growth associated protein 43 & $B-50$ & 23.52 & $\mathrm{P}$ & 232.10 \\
\hline procollagen C-endopeptidase enhancer 2 & PCPE2 & 117.81 & $\mathrm{P}$ & 224.83 \\
\hline sorbin and SH3 domain containing 2 & SORB2 & 10.65 & $P$ & 192.25 \\
\hline myozenin 2 & MYOZ2 & 6.53 & $\mathrm{P}$ & 139.50 \\
\hline serpin peptidase inhibitor, clade B (ovalbumin), member 2 transcript variant 2 & PAl2 & 260.13 & $\mathrm{P}$ & 133.32 \\
\hline doublecortin-like kinase 1 & DCLK & 19.11 & $\mathrm{P}$ & 112.57 \\
\hline formyl peptide receptor-like 2 & FPRL2 & 3.24 & $\mathrm{P}$ & 111.02 \\
\hline contactin associated protein-like 3 & CASPR3 & 5.09 & $\mathrm{P}$ & 106.75 \\
\hline integrin, beta-like 1 (with EGF-like repeat domains) & ITGBLI & 13.35 & $\mathrm{P}$ & 82.92 \\
\hline collagen, type IV, alpha 6 & COL4A6 & 76.71 & $\mathrm{P}$ & 77.06 \\
\hline myc target 1 & MYCT1 & 28.15 & $P$ & 73.88 \\
\hline S100 calcium binding protein A4 & S100A4 & 103.88 & $P$ & 72.30 \\
\hline phosphodiesterase $1 \mathrm{~A}$, calmodulin-dependent & HSPDEA1 & 12.50 & $\mathrm{P}$ & 71.51 \\
\hline neurofilament, light polypeptide $68 \mathrm{kDa}$ & NEFL & 5.71 & $P$ & 69.33 \\
\hline ADAMTS-like 1 & ADAMTSR1 & 3.24 & $\mathrm{P}$ & 68.55 \\
\hline early B-cell factor 1 & $E B F$ & 4.57 & $\mathrm{P}$ & 60.80 \\
\hline $\begin{array}{l}\text { ST6 (alpha-N-acetyl-neuraminyl-2,3-beta-galactosyl-1,3)-N-acetylgalactosaminide alpha-2,6- } \\
\text { sialyltransferase } 5\end{array}$ & SIAT7E & 0.02 & $P$ & 3943.41 \\
\hline fibrillin 2 (congenital contractural arachnodactyly) & FBN2 & 0.05 & $\mathrm{P}$ & 1035.17 \\
\hline fibroblast growth factor receptor 2 & FGFR2 & 0.04 & $\mathrm{P}$ & 684.03 \\
\hline pregnancy specific beta-1-glycoprotein 5 & PSG & 0.07 & $\mathrm{P}$ & 349.77 \\
\hline Sal-like 1 (Drosophila) & SALL1 & 0.03 & $\mathrm{P}$ & 312.29 \\
\hline membrane metallo-endopeptidase & MME & 0.05 & $\mathrm{P}$ & 274.25 \\
\hline odz, odd Oz/ten-m homolog 2 (Drosophila) & TEN-M2 & 0.93 & $\mathrm{P}$ & 134.10 \\
\hline R-spondin 3 homolog (Xenopus laevis) & RSPO3 & 0.4 & P & 70.16 \\
\hline bone morphogenetic protein 2 & $B M P 2 A$ & 1.19 & $\mathrm{P}$ & 68.96 \\
\hline neuroligin 4, Y-linked & NLGN4Y & 0.09 & $\mathrm{P}$ & 68.62 \\
\hline matrix-remodelling associated 5 & DKFZp564l1922 & 1.31 & $\mathrm{P}$ & 57.89 \\
\hline collagen, type IV, alpha 4 & COL4A4 & 0.67 & $\mathrm{P}$ & 49.71 \\
\hline bradykinin receptor B1 & BRADYB1 & 1.61 & P & 48.96 \\
\hline microfibrillar-associated protein 4 & MFAP4 & 0.3 & $P$ & 32.40 \\
\hline matrix metallopeptidase 3 (stromelysin 1, progelatinase) & $M M P-3$ & 0.85 & P & 30.01 \\
\hline chromosome 13 open reading frame 15 & RGC32 & 1.69 & $\mathrm{P}$ & 28.40 \\
\hline fibroblast growth factor 13 & FGF13 & 0.38 & P & 28.15 \\
\hline ephrin receptor A5 & EPHA5 & 0.40 & $\mathrm{P}$ & 25.68 \\
\hline interleukin 24 & $\| L-24$ & 1.68 & $P$ & 25.27 \\
\hline
\end{tabular}

Only those having transcripts, not EST or clones in CDNA library are listed.

$\mathrm{P}=$ presence to detectable intensity

positive (Table 4). Among these positive cases, $58 \%$ of them showed high expression levels. High expression of PN was observed in well- (Fig 3A), moderately- (Fig 3B) and poorly-differentiated malignant tissues (Fig 3C). For PN-negative CCA tissues, only $17 \%(9 / 52)$ were in this group in which no PN was detected in either fibroblasts or cancer cells (Fig 3D). In contrast, benign liver tissues showed no (2/8) to slight (6/8) PN expression. Similar to benign liver tissues, hepatocellular carcinoma revealed low PN expression in their stromal cells (Fig 3E and 3F). Moreover, double immunofluorescence staining revealed co-localization of $\alpha$-SMA and PN in the fibroblasts within cancerous area (Fig 3G).

Cumulative survival of CCA patients with low or high PN expression in cancer stromal fibroblasts was analyzed using the Kaplan-Meier method. The patients with 
Table 2 Gene ontology of common up-regulated genes. Only genes in the top-five ranking of each group are shown.

\begin{tabular}{|c|c|c|c|}
\hline Gene ontology (\%) & $\begin{array}{l}\text { Accession } \\
\text { no. }\end{array}$ & Description & Ratio \\
\hline \multirow[t]{5}{*}{ Cellular metabolism (23.7\%) } & NM_000909 & neuropeptide $Y$ receptor $Y 1$ & 416.71 \\
\hline & NM_004734 & doublecortin-like kinase 1 & 112.57 \\
\hline & NM_002961 & S100 calcium binding protein A4 & 72.30 \\
\hline & AF208502 & early B-cell factor 1 & 60.80 \\
\hline & AW004016 & ST6 beta-galactosamide alpha-2,6 sialyltransferase 2 & 59.04 \\
\hline \multirow[t]{5}{*}{ Protein binding (20.8\%) } & BF449063 & collagen, type XIV, alpha 1 (undulin) & 245.03 \\
\hline & NM_002045 & growth associated protein 43 & 232.10 \\
\hline & Al659533 & sorbin and $\mathrm{SH} 3$ domain containing 2 & 192.25 \\
\hline & BF939176 & myozenin 2 & 139.5 \\
\hline & AF333769 & contactin associated protein-like 3 & 106.75 \\
\hline \multirow[t]{5}{*}{ Signal transduction (10.9\%) } & AW026543 & formyl peptide receptor-like 2 & 111.02 \\
\hline & NM_004791 & integrin, beta-like 1 & 82.92 \\
\hline & NM_005019 & phosphodiesterase $1 \mathrm{~A}$ & 71.51 \\
\hline & AF159570 & regulator of G-protein signalling 5 & 49.64 \\
\hline & W67461 & angiopoietin-like 1 & 49.16 \\
\hline \multirow[t]{5}{*}{ Extracellular region (7.8\%) } & NM_001086 & arylacetamide deacetylase (esterase) & 956.45 \\
\hline & Al808090 & Sparc/osteonectin, cwcv and kazal-like domains proteoglycan (testican) 3 & 669.24 \\
\hline & NM_013363 & procollagen C-endopeptidase enhancer 2 & 224.83 \\
\hline & Al889941 & collagen, type IV, alpha 6 & 77.06 \\
\hline & NM_052866 & a disintegrin and metalloproteinase with thrombospondin motif-like 1 & 68.55 \\
\hline \multirow[t]{5}{*}{ Transcription factor (7.5\%) } & AF332197 & sine oculis homeobox homolog 2 & 44.20 \\
\hline & Al681917 & iroquois homeobox protein 3 & 35.34 \\
\hline & NM_020639 & receptor-interacting serine-threonine kinase 4 & 29.41 \\
\hline & AK023792 & PBX/knotted 1 homeobox 2 & 29.40 \\
\hline & AF208967 & paternally expressed 3 & 26.74 \\
\hline \multirow[t]{5}{*}{ Protein modification (5.5\%) } & AW975934 & Titin & 32.01 \\
\hline & NM_020639 & receptor-interacting serine-threonine kinase 4 & 29.41 \\
\hline & NM_000222 & v-kit Hardy-Zuckerman 4 feline sarcoma viral oncogene homolog & 25.21 \\
\hline & BF446673 & hemicentin 1 & 18.96 \\
\hline & NM_002848 & protein tyrosine phosphatase, receptor type, $\mathrm{O}$ & 14.58 \\
\hline \multirow[t]{5}{*}{ Receptor (4.8\%) } & BF941499 & G protein-coupled receptor 116 & 35.62 \\
\hline & L35594 & ectonucleotide pyrophosphatase/phosphodiesterase 2 & 32.11 \\
\hline & NM_002820 & parathyroid hormone-like hormone & 30.44 \\
\hline & U61276 & jagged 1 (Alagille syndrome) & 19.60 \\
\hline & AK022548 & integrin, alpha 7 & 15.62 \\
\hline \multirow[t]{5}{*}{ Cell differentiation (4.3\%) } & AA343027 & $\begin{array}{l}\text { Sema domain, immunoglobulin domain (lg), short basic domain, secreted, } \\
\text { (semaphorin) 3D }\end{array}$ & 67.06 \\
\hline & NM_000216 & Kallmann syndrome 1 sequence & 27.91 \\
\hline & AL560266 & Fc receptor-like A & 19.61 \\
\hline & AA127691 & neuropilin 2 & 19.35 \\
\hline & NM_002506 & nerve growth factor, beta polypeptide & 19.11 \\
\hline \multirow[t]{5}{*}{ Cell adhesion (3.5\%) } & NM_006727 & cadherin 10, type 2 (T2-cadherin) & 55.43 \\
\hline & NM_000072 & CD36 molecule (thrombospondin receptor) & 40.71 \\
\hline & AL573851 & endothelial cell adhesion molecule & 22.52 \\
\hline & N69091 & protocadherin 17 & 22.32 \\
\hline & AA489646 & protocadherin beta 13 & 19.36 \\
\hline \multirow[t]{4}{*}{ Cell cycle (2.4\%) } & NM_003914 & cyclin A1 & 34.8 \\
\hline & NM_015714 & G0/G1switch 2 & 26.62 \\
\hline & NM_001759 & cyclin D2 & 16.45 \\
\hline & NM_001992 & coagulation factor II (thrombin) receptor & 13.90 \\
\hline
\end{tabular}


Table 2: Gene ontology of common up-regulated genes. Only genes in the top-five ranking of each group are shown. (Continued)

\begin{tabular}{|c|c|c|c|}
\hline & AK024082 & Tousled-like kinase 2 & 11.09 \\
\hline \multirow[t]{5}{*}{ Cell motility (2.2\%) } & NM_005045 & reelin & 17.30 \\
\hline & NM_003062 & slit homolog 3 (Drosophila) & 5.12 \\
\hline & M21121 & chemokine (C-C motif) ligand 5 & 5.06 \\
\hline & NM_014795 & zinc finger E-box binding homeobox 2 & 4.85 \\
\hline & D45864 & protein kinase, cGMP-dependent, type I & 4.74 \\
\hline \multirow[t]{5}{*}{ Proteolysis (2.0\%) } & NM_001870 & carboxypeptidase A3 (mast cell) & 20.01 \\
\hline & NM_024539 & ring finger protein 128 & 12.68 \\
\hline & AL574912 & protease, serine, 35 & 11.59 \\
\hline & NM_001873 & carboxypeptidase E & 9.45 \\
\hline & NM_000892 & kallikrein B, plasma (Fletcher factor) 1 & 6.40 \\
\hline \multirow[t]{5}{*}{ Cell proliferation (2.0\%) } & U77914 & jagged 1 (Alagille syndrome) & 16.76 \\
\hline & NM_004624 & vasoactive intestinal peptide receptor 1 & 13.07 \\
\hline & BF514079 & Kruppel-like factor 4 (gut) & 12.89 \\
\hline & NM_001432 & epiregulin & 11.98 \\
\hline & BC003355 & laminin, alpha 5 & 10.36 \\
\hline \multirow[t]{5}{*}{ Apoptosis (1.6\%) } & NM_002575 & serpin peptidase inhibitor & 133.32 \\
\hline & NM_000557 & growth differentiation factor 5 & 14.79 \\
\hline & NM_003728 & unc-5 homolog C (C. elegans) & 9.60 \\
\hline & BF432648 & tumor necrosis factor receptor superfamily & 8.73 \\
\hline & NM_003551 & non-metastatic cells 5, protein expressed in (nucleoside-diphosphate kinase) & 6.80 \\
\hline \multirow{5}{*}{$\begin{array}{l}\text { ECM organization and biosynthesis } \\
(0.9 \%)\end{array}$} & BC001186 & protocadherin beta 5 & 15.90 \\
\hline & M25813 & tenascin XB & 12.46 \\
\hline & NM_002380 & matrilin 2 & 4.89 \\
\hline & AY140646 & periostin, osteoblast specific factor 2 & 4.89 \\
\hline & NM_004612 & $\begin{array}{l}\text { transforming growth factor, beta receptor I (activin A receptor type II-like kinase, } 53 \\
\mathrm{kDa}\end{array}$ & 4.56 \\
\hline
\end{tabular}

survival time under $14 \mathrm{~d}$ were identified as peri-operative deaths $(\mathrm{n}=1)$ and excluded from the analysis. Median survival time was $395 \pm 157 \mathrm{~d}$ for patients with low and $179 \pm 35 \mathrm{~d}$ for patients with high PN expression. We found that the patients with high PN positive fibroblasts had statistically significantly shorter survival times than those with low PN positive fibroblasts $(P=0.026)$ (Fig 4). The prognostic value of PN expression and other clinicopathological factors among CCA patients was analyzed using multivariate Cox Proportional Hazard Regression model. The results revealed that high $\mathrm{PN}$ expression $(\mathrm{HR}=2.02, P=0.045)$, and the presence of lymph node metastasis ( $\mathrm{HR}=3.13, P=0.002)$ were the independent risk factors for the overall survival of CCA patients after hepatectomy (Table 5). However, lymph node metastasis and other clinical data showed no association with PN expression (Table 6).

\section{PN promotes proliferation and invasion of CCA cells}

PN could induce proliferation of KKU-M156, KKU-M213 and KKU-M055 CCA cell lines (Fig 5A-C), but not KKU100 (Fig 5D). In addition, KKU-M156, KKU-M213 and KKU-M055 responded to the proliferative effect of optimal PN concentration in a time dependent manner with statistical significance at the $24 \mathrm{~h}$-treatment for all cell types (Fig 5E). To reinforce the proliferation effect of PN on CCA cell lines, colony formation assay with and without soft agar were performed and the result indicated the increased numbers of colonies in the condition of PN treatment in comparison to the negative control without PN stimulation (Fig 5F). In addition, flow cytometric analysis indicated an increased number of KKU-M213 and KKU-M156 cells distributed in S+G2/M when exposed to PN (Fig 6A and 6B).

To address the invasion effect of PN on CCA cells, the invasion assay of cell lines with high $I T G \alpha_{5}$ expression was performed in a Boyden chamber. The results showed that exogenous PN could markedly induce invasion of KKU-M156 and KKU-M213 CCA cell lines up to around $210 \%$ and $230 \%$ of cells without PN treatment (Fig 6C).

\section{Knockdown of ITG $\alpha 5$ attenuates PN-induced proliferation and invasion}

Treatment of CCA cells with siITG $\alpha_{5}$ and lipofectamine (mock) for $6 \mathrm{~h}$ did not affect cell viability (Fig 7A). The 
Table 3 Gene ontology of common down-regulated genes.

\begin{tabular}{|c|c|c|c|}
\hline Gene ontology (\%) & $\begin{array}{l}\text { Accession } \\
\text { no. }\end{array}$ & Description & Ratio \\
\hline \multirow[t]{5}{*}{$\begin{array}{l}\text { Cellular metabolism } \\
(31.6 \%)\end{array}$} & NM_030965 & $\begin{array}{l}\text { ST6 (alpha-N-acetyl-neuraminyl-2,3-beta-galactosyl-1,3)-N-acetylgalactosaminide alpha-2,6- } \\
\text { sialyltransferase } 5\end{array}$ & 3943.41 \\
\hline & NM_022969 & fibroblast growth factor receptor 2 & 684.03 \\
\hline & AU152837 & Sal-like 1 (Drosophila) & 312.29 \\
\hline & NM_007287 & membrane metallo-endopeptidase & 73.38 \\
\hline & BF589322 & R-spondin 3 homolog (Xenopus laevis) & 70.16 \\
\hline \multirow{5}{*}{$\begin{array}{l}\text { Signal transduction } \\
(17.8 \%)\end{array}$} & NM_001200 & bone morphogenetic protein 2 & 68.96 \\
\hline & NM_000710 & bradykinin receptor B1 & 48.96 \\
\hline & R72286 & microfibrillar-associated protein 4 & 32.40 \\
\hline & NM_004114 & fibroblast growth factor 13 & 28.15 \\
\hline & BE218107 & EPH receptor A5 & 25.68 \\
\hline \multirow{5}{*}{$\begin{array}{l}\text { Transcription factor } \\
(11.5 \%)\end{array}$} & AJ277914 & LIM homeobox 9 & 25.01 \\
\hline & NM_001452 & forkhead box F2 & 18.08 \\
\hline & AA705845 & transducin-like enhancer of split 4 (E(sp1) homolog, Drosophila) & 17.16 \\
\hline & BG261252 & ecotropic viral integration site 1 & 11.58 \\
\hline & NM_020327 & activin A receptor, type IB & 9.32 \\
\hline \multirow{5}{*}{$\begin{array}{l}\text { Protein modification } \\
(7.9 \%)\end{array}$} & AF245505 & matrix-remodelling associated 5 & 57.89 \\
\hline & AA725644 & ubiquitin specific peptidase 42 & 18.73 \\
\hline & NM_001982 & v-erb-b2 erythroblastic leukemia viral oncogene homolog 3 (avian) & 11.34 \\
\hline & AV727260 & protein tyrosine phosphatase, receptor type, D & 10.93 \\
\hline & NM_002570 & proprotein convertase subtilisin/kexin type 6 & 9.83 \\
\hline \multirow[t]{5}{*}{ Cell differentiation (6.2\%) } & NM_000641 & interleukin 11 & 17.51 \\
\hline & BC006454 & growth arrest-specific 7 & 15.20 \\
\hline & M69148 & midkine (neurite growth-promoting factor 2) & 14.03 \\
\hline & NM_003991 & endothelin receptor type B & 10.85 \\
\hline & Al758962 & EPH receptor A4 & 7.15 \\
\hline \multirow[t]{5}{*}{ Cell adhesion (5.9\%) } & NM_001999 & fibrillin 2 & 1035.17 \\
\hline & NM_014893 & neuroligin 4, Y-linked & 68.62 \\
\hline & Al694562 & collagen, type IV, alpha 3 & 22.21 \\
\hline & NM_005864 & embryonal Fyn-associated substrate & 8.44 \\
\hline & AU146651 & collagen, type XII, alpha 1 & 4.89 \\
\hline \multirow[t]{5}{*}{ Cell cycle (5.9\%) } & NM_014059 & chromosome 13 open reading frame 15 & 28.40 \\
\hline & M19701 & retinoblastoma 1 (including osteosarcoma) & 4.93 \\
\hline & NM_002009 & fibroblast growth factor 7 & 4.44 \\
\hline & NM_014703 & Vpr (HIV-1) binding protein & 3.92 \\
\hline & Al983033 & DEAD/H box polypeptide 12 & 3.91 \\
\hline \multirow[t]{5}{*}{ Cell motility (4.7\%) } & NM_002784 & pregnancy specific beta-1-glycoprotein 9 & 69.22 \\
\hline & X99268 & twist homolog 1 & 5.45 \\
\hline & NM_015180 & spectrin repeat containing, nuclear envelope 2 & 3.81 \\
\hline & Al990816 & laminin, alpha 1 & 3.59 \\
\hline & N90777 & neuropilin 2 & 3.57 \\
\hline \multirow[t]{5}{*}{ Cell proliferation (4.5\%) } & NM_016931 & NADPH oxidase 4 & 5.79 \\
\hline & AF064826 & glypican 4 & 4.31 \\
\hline & NM_004525 & low density lipoprotein-related protein 2 & 3.85 \\
\hline & NM_001963 & epidermal growth factor (beta-urogastrone) & 3.70 \\
\hline & AF064103 & CDC14 cell division cycle 14 homolog A & 3.67 \\
\hline \multirow[t]{2}{*}{ Apoptosis (4.0\%) } & NM_006850 & interleukin 24 & 25.27 \\
\hline & NM 002135 & nuclear receptor subfamily 4 , group $A$, member 1 & 5.48 \\
\hline
\end{tabular}


Table 3: Gene ontology of common down-regulated genes. (Continued)

\begin{tabular}{lll}
\hline NM_003823 & tumor necrosis factor receptor superfamily & 4.59 \\
AJ301610 & glutamate receptor, ionotropic, kainate 2 & 3.92 \\
NM_005809 & peroxiredoxin 2 & 3.90 \\
\hline
\end{tabular}

Only genes in the top-five ranking of each group are shown.

reduction of $I T G \alpha_{5}$ expression was observed to be $88 \%$ of that expressed in both KKU-M213 and KKU-M156 CCA cells without transient knockdown of this gene (Fig 7B). The knockdown effect could be detected up to $72 \mathrm{~h}$ after siITG $\alpha_{5}$ treatment (data not shown). Thus, the subsequent investigations of cell proliferation and invasion were done within $72 \mathrm{~h}$ after transient knockdown with siITG $\alpha_{5}$.

The reduction of $I T G \alpha_{5}$ expressions in both KKUM213 and KKU-M156 CCA cells resulted in a significant decreased response of cells to $\mathrm{PN}$-induced cell proliferation and invasion (Fig 7C and 7D). A 104\% of KKU-M213 cell proliferation induction was detected in si $I T G \alpha_{5}$-treated cells exposed to PN, whereas cell proliferation could increase up to $130 \%$ in cells with intrinsic $I T G \alpha_{5}$ expression (Fig 7C). In the same manner, KKU-
M156 showed 118\% and 98\% of cell proliferation induction observed in cells untreated and treated with siITG $\alpha_{5}$. Both ITG $\alpha_{5}$-knockdown CCA cell lines did not respond to $\mathrm{PN}$-activated cell invasion whereas $\mathrm{PN}$ dramatically induced invasion of both cell lines having normal intrinsic $I T G \alpha_{5}$ expression (168\% for KKU-M156 and $172 \%$ for KKU-M213) (Fig 7D). Finally, cells with high $I T G \alpha_{5}$ expressions were more susceptible to PN stimulation to proliferate and invade than cells without or minimal $I T G \alpha_{5}$ expression.

\section{Discussion}

Cancer-associated fibroblasts have been recognized for their impact in the genesis, promotion and progression of many carcinomas and highlighted in several reviews $[8,25]$. CCA is notoriously associated with dense
A

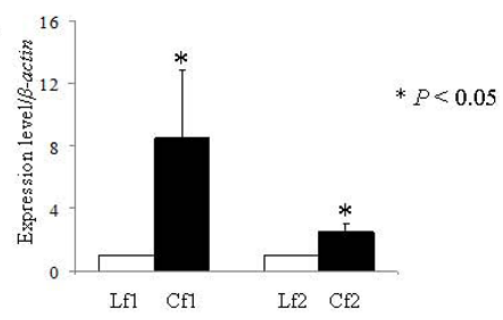

B

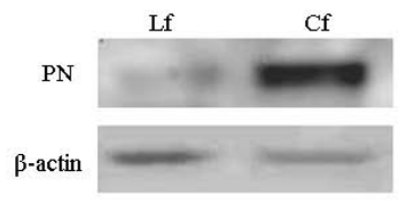

D

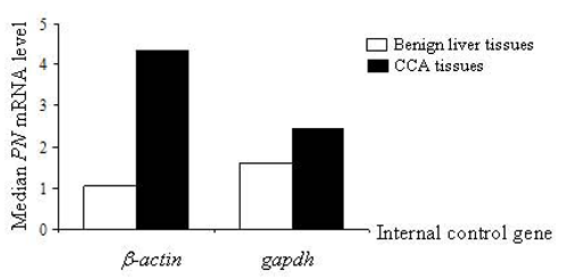

C Expression level $\beta$-actin (Normalized with Lf2)

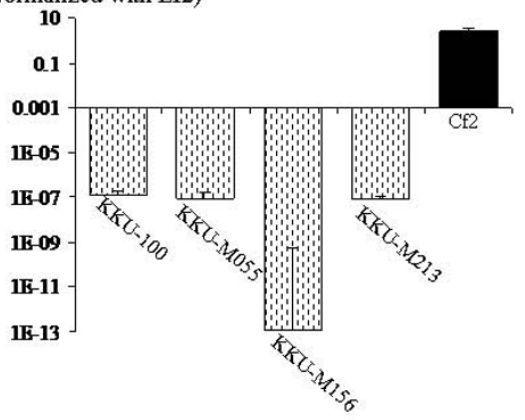

E

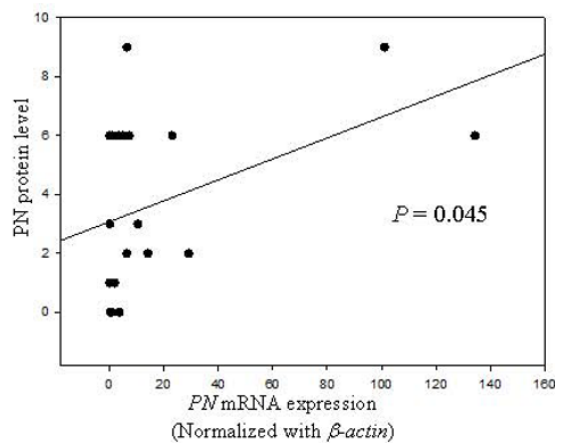

Figure 2 PN expressions in Cfs, CCA cell lines and CCA tissues. PN expression in Cfs measured by real time RT-PCR (A) and western blot analysis (B) using different biological preparations of Cfs and Lfs from those used in microarray. The expression of PN in CCA cell lines and fibroblasts extracted from CCA tissues is graphically depicted (C). Results are expressed as mean \pm SD of three independent experiments. Means of PN mRNA expression levels were measured in 20 CCA cases and compared to 5 cases of benign liver diseases using both $\beta$-actin and gapdh as internal controls (D). The positive correlation of mRNA and protein levels of PN in CCA tissues is shown with statistical significance by Spearman correlation analysis (E). 

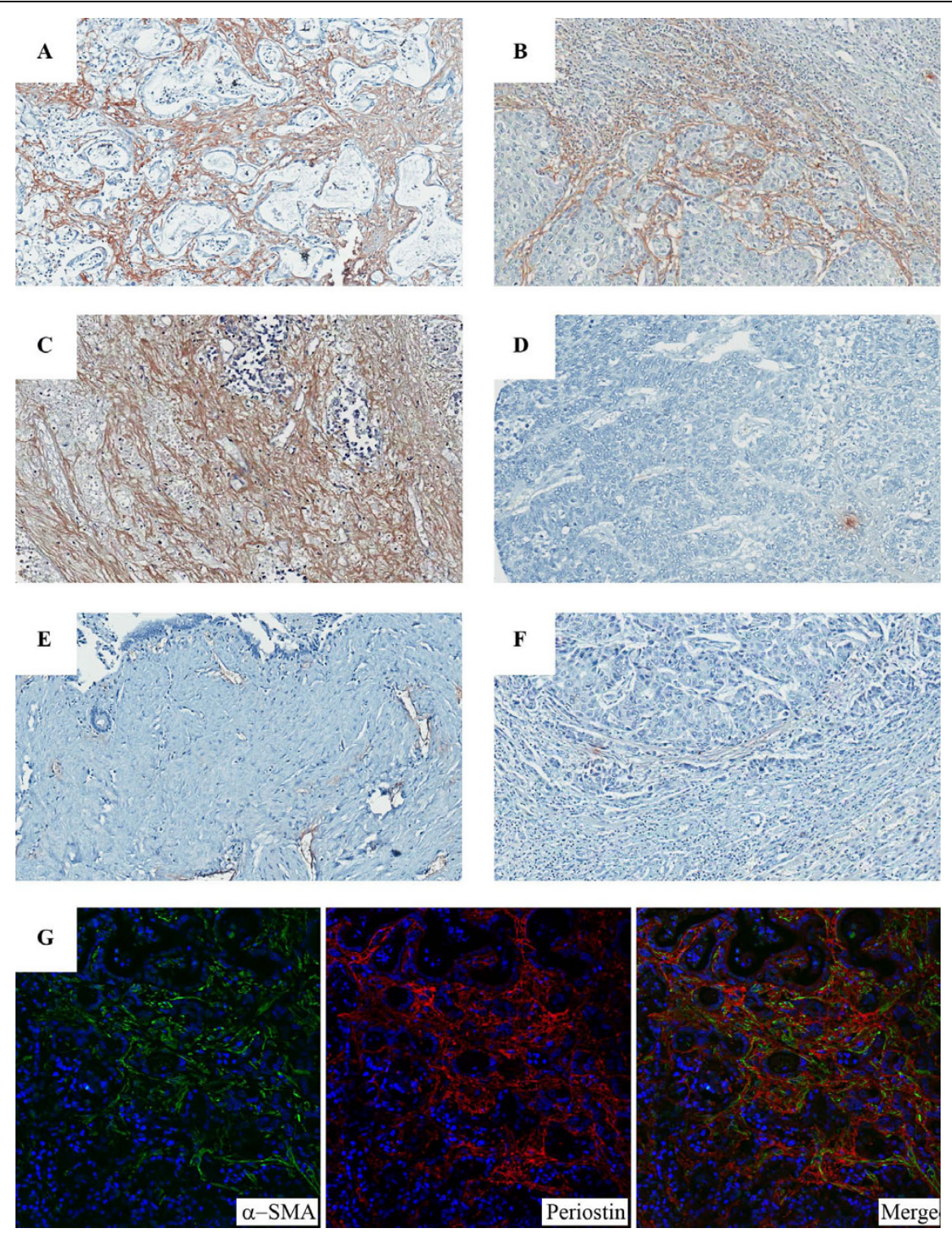

Figure 3 Immunohistochemical staining of PN in CCA tissues. The expression of PN was localized in fibroblasts but not cancer cells. High expression of PN was observed in well- (A), moderately- (B) and poorly-differentiated tissues (C), whereas PN negative staining CCA tissue was demonstrated (D). Benign liver tissue (E) and hepatocellular carcinoma (F) showed no to slight expression. Magnification, 100x. Double immunofluorescence staining showed co-expression of PN and $\alpha$-SMA in CCA stromal fibroblasts (G). Magnification, 200x.

desmoplastic stroma with activated fibroblasts $[5,6]$. Relatively little, however, is known about the contribution of the stromal fibroblasts to CCA. The authors in the present group have recently shown that CCA stromal fibroblasts, with and without direct interaction with cancer cells could induce cancer cell proliferation [6]. Herein, this study focused on the gene expression profile of CCA-derived fibroblasts in order to investigate the molecular mechanism of how fibroblasts induce a favorable microenvironment to promote cancer. Even though the current study is limited to a single cancer fibroblast line isolated from a single CCA patient, the validity of array results was strengthened by comparing gene expression levels in cancer fibroblasts to the two lines of normal fibroblasts; one isolated from the same CCA patient and the other from a second patient. Only genes in cancer fibroblasts altered from both normal fibroblast lines were investigated as the common up- or down-regulated genes. This is to provide evidence that the fibroblasts used in our study are valid representatives of fibroblasts found in CCA.

By comparing gene profiles in fibroblasts from CCA with those of other tumor types, it is suggested that CCA fibroblasts display not only common genotypes for 


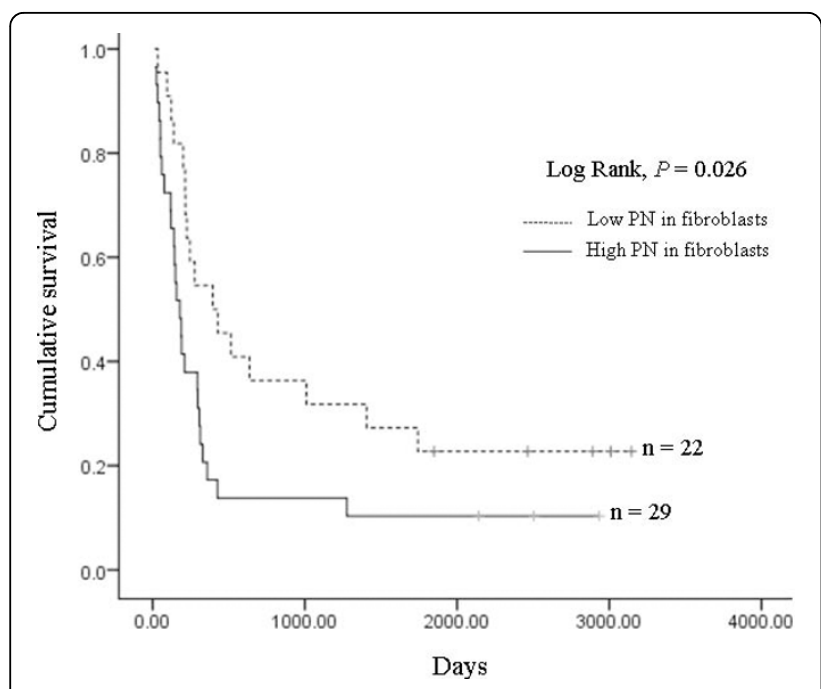

Figure 4 Multivariate analysis using Kaplan-Meier method. Cumulative survival analysis showed significantly shorter survival time of the patients with high PN expression in fibroblasts when compared to those who had low PN expression in fibroblasts $(P=$ 0.026).

activated cells but also unique characteristics. Genes involved in metabolism of cells needed to be up-regulated in order to support the active function of CCA stromal fibroblasts to produce many supporting proteins in the cancer environment. Neuropeptide Y receptor Y1 has been indicated to receive the activation signal to induce neuroproliferation [26] and doublecortin-like kinase 1, a microtubule-associated active protein kinase expressed in growth cones of postmitotic neurons [27] may help facilitate fibroblast proliferation. In similar to human basal cell carcinoma fibroblasts [14], SPARC or osteonectin, was also over-expressed in CCA-derived fibroblasts. SPARC-null mice were recently demonstrated to resist UV-induced squamous cell carcinoma, suggesting a tumor-promoting role of SPARC [28]. In contrast to the cancer-associated fibroblasts in metastatic colon cancer to the liver which showed down-regulation of SDF-1 [18], CCA-derived fibroblasts had upregulated $S D F-1$ (data not shown).
The highly up-regulated genes in CCA-derived fibroblasts showed several interesting functions involved in cancer progression. Serpin peptidase inhibitor, clade B member 2 (SERPINE2) or plasminogen activator inhibitor type 2 (PAI2) is involved in cancer invasion and metastasis by controlling serine protease urokinase plasminogen activator. In a recent review, several studies led to the suggestion that the significance of PAI2 expression on prognosis of cancers is organ context-dependent [29]. In breast cancer, PAI2 was expressed in both stromal and tumor cells and associated with prolonged disease-free survival [30]. In contrast, high levels of PAI2 in endometrial cancer were reported to correlate with the invasion potential of the cancer [31]. S100 calcium binding protein A4 (S100A4) has been revealed as the metastasis-inducing protein [32]. Genes such as procollagen C-endopeptidase enhancer 2 (PCPE2) were also detected which may involve in collagen synthesis [33]. These results support the function of fibroblasts in CCA to promote a desmoplastic reaction. For down-regulated genes, bone morphogenetic protein $2(B M P 2 A)$, a multi-functional growth factor belonging to the transforming growth factor- $\beta$ superfamily was decreased in CCA fibroblasts as reported in breast cancer-derived fibroblasts [13]. BMP2A-encoding protein has been elucidated to induce hypophosphorylation of retinoblastoma protein causing cell cycle arrest [34]. Hence, decreased BMP2A in the CCA microenvironment may promote cancer cells to enter the cell cycle. Moreover, a decreased level of interleukin 24 (IL-24), an apoptotic inducible cytokine [35], in cancer tissues, attenuates cancer cells from undergoing apoptosis. The response gene to complement 32 (RGC32), a novel p53inducible gene, and bradykinin receptor $\mathrm{B} 1$ (BRADYB1) decreased expression in CCA-derived fibroblasts. Being intracellular protein and membrane receptor, respectively, RGC32 and BRADYB1 have elucidated the function of inhibition of fibroblast cell proliferation [36,37]. It seems possible to conclude that down-regulated genes in fibroblasts encode proteins, if acting in the intracellular region, can inhibit the proliferation of fibroblasts themselves, but if they exist in the extracellular region, they may involve inhibition of cancer cell proliferation. This evidence strengthens the roles of fibroblast-derived pro-

Table 4 PN expression in CCA tissues compared to benign liver tissues and hepatocellular carcinoma.

\begin{tabular}{ccccc}
\hline Tissues & $\begin{array}{c}\text { Total cases } \\
(\mathbf{n})\end{array}$ & \multicolumn{3}{c}{ PN expression in fibroblasts } \\
\cline { 3 - 5 } & & Negative & \multicolumn{2}{c}{ Positive } \\
Lew & $9(17 \%)$ & $13(25 \%)$ & $30(58 \%)$ \\
CCA & 52 & $2(25 \%)$ & $6(75 \%)$ & $0(0 \%)$ \\
Benign liver tissue & 8 & $1(25 \%)$ & $3(75 \%)$ & $0(0 \%)$ \\
\hline
\end{tabular}


Table 5 Multivariate analysis by Cox proportional hazard regression model for the evaluation of prognostic factors.

\begin{tabular}{|c|c|c|c|c|}
\hline $\begin{array}{l}\text { Variable } \\
\text { (No. of patients) }\end{array}$ & $\begin{array}{c}\text { No. of dead } \\
\text { patients } \\
\text { (5-yr survival cut-off) }\end{array}$ & $\begin{array}{c}\text { Hazard ratio } \\
(\mathrm{HR}) \\
\end{array}$ & $\begin{array}{l}95 \% \text { confidence interval } \\
(\mathrm{Cl})\end{array}$ & $P$ \\
\hline \multicolumn{5}{|l|}{ Age in years } \\
\hline$\leq 57(25)$ & 21 & 1 & & \\
\hline$>57(26)$ & 22 & 1.25 & $0.62-2.48$ & 0.533 \\
\hline \multicolumn{5}{|l|}{ PN expression } \\
\hline Low (22) & 17 & 1 & & \\
\hline High (29) & 26 & 2.02 & $1.02-4.02$ & $0.045^{*}$ \\
\hline \multicolumn{5}{|l|}{ Lymph node metastasis } \\
\hline Absence (36) & 28 & 1 & & \\
\hline Presence (15) & 15 & 3.13 & $1.54-6.35$ & $0.002^{*}$ \\
\hline \multicolumn{5}{|l|}{ Histological type } \\
\hline Well-differentiated (20) & 16 & 1 & & \\
\hline Moderately-differentiated (8) & 8 & 2.77 & $1.10-6.98$ & $0.031^{*}$ \\
\hline Poorly-differentiated (8) & 7 & 1.64 & $0.63-4.29$ & 0.310 \\
\hline Papillary (15) & 12 & 0.60 & $0.25-1.44$ & 0.254 \\
\hline \multicolumn{5}{|l|}{ Tumor size $(\mathrm{cm})$} \\
\hline$\leq 5(28)$ & 23 & 1 & & \\
\hline$>5(23)$ & 20 & 1.49 & $0.76-2.94$ & 0.251 \\
\hline
\end{tabular}

* $P$ value of equal or less than 0.05 means statistical significance

teins released into a tumor environment to induce a high proliferative capability of cancer cells.

Fibroblasts have been proposed the bipolar effects in cancers [38]. In our microarray results, ADAMTS-like 1 (ADAMTSR1) was over-expressed in CCA-derived fibroblasts. The ADAMTS-like proteins have been discussed as the enhancers of ADAMTS proteases [39]. Since some ADAMTS have been proven to be anti-angiogenic factors [40] partly via the trapping of vascular endothelial growth factor by thrombospondin motifs of ADAMTS [41]. So up-regulation of ADAMTSR1 in fibroblasts may inhibit angiogenesis. Moreover, stromelysin-1 or MMP-3 which can degrade ECM and induce cancer invasion and metastasis, showed the decreased expression in fibroblasts. Taken together, the increased expression of ADAMTSR 1 and the decreased expression of $M M P-3$ may highlight fibroblasts in term of suppressing CCA progression.

Table 6 Correlation between PN expression level and clinicopathological parameters.

\begin{tabular}{|c|c|c|c|c|c|c|}
\hline \multirow[t]{2}{*}{ Variable } & \multirow[t]{2}{*}{$\mathbf{n}$} & \multicolumn{2}{|c|}{ PN expression (\%) } & \multirow{2}{*}{$\begin{array}{c}\text { Univariate analysis } \\
P\end{array}$} & \multicolumn{2}{|c|}{ Multivariate analysis } \\
\hline & & Low & High & & $\mathrm{HR}$ & $P$ \\
\hline Age in years & & & & 0.575 & & \\
\hline$\leq 57$ & 26 & $10(38.5)$ & $16(61.5)$ & & 1 & \\
\hline$>57$ & 26 & $12(46.2)$ & $14(53.8)$ & & 0.899 & 0.870 \\
\hline Sex & & & & 0.375 & & \\
\hline Female & 20 & $10(50.0)$ & $10(50.0)$ & & 1 & \\
\hline Male & 32 & $12(37.5)$ & $20(62.5)$ & & 1.638 & 0.452 \\
\hline Histological type & & & & 0.083 & & \\
\hline Well-differentiated & 21 & $8(38.1)$ & $13(61.9)$ & & 1 & \\
\hline Moderately-differentiated & 8 & $1(12.5)$ & $7(87.5)$ & & 3.720 & 0.271 \\
\hline Poorly-differentiated & 8 & $6(75.0)$ & $2(25.0)$ & & 0.184 & 0.86 \\
\hline Papillary & 15 & $7(46.7)$ & $8(53.3)$ & & 0.611 & 0.505 \\
\hline Tumor size $(\mathrm{cm})$ & & & & 0.123 & & \\
\hline$\leq 5$ & 29 & $15(51.7)$ & $14(48.3)$ & & 1 & \\
\hline$>5$ & 23 & $7(30.4)$ & $16(69.6)$ & & 2.493 & 0.161 \\
\hline Lymph node metastasis & & & & 0.830 & & \\
\hline Absence & 37 & $16(43.2)$ & $21(56.8)$ & & 1 & \\
\hline Presence & 15 & $6(40.0)$ & $9(60.0)$ & & 1.459 & 0.590 \\
\hline
\end{tabular}




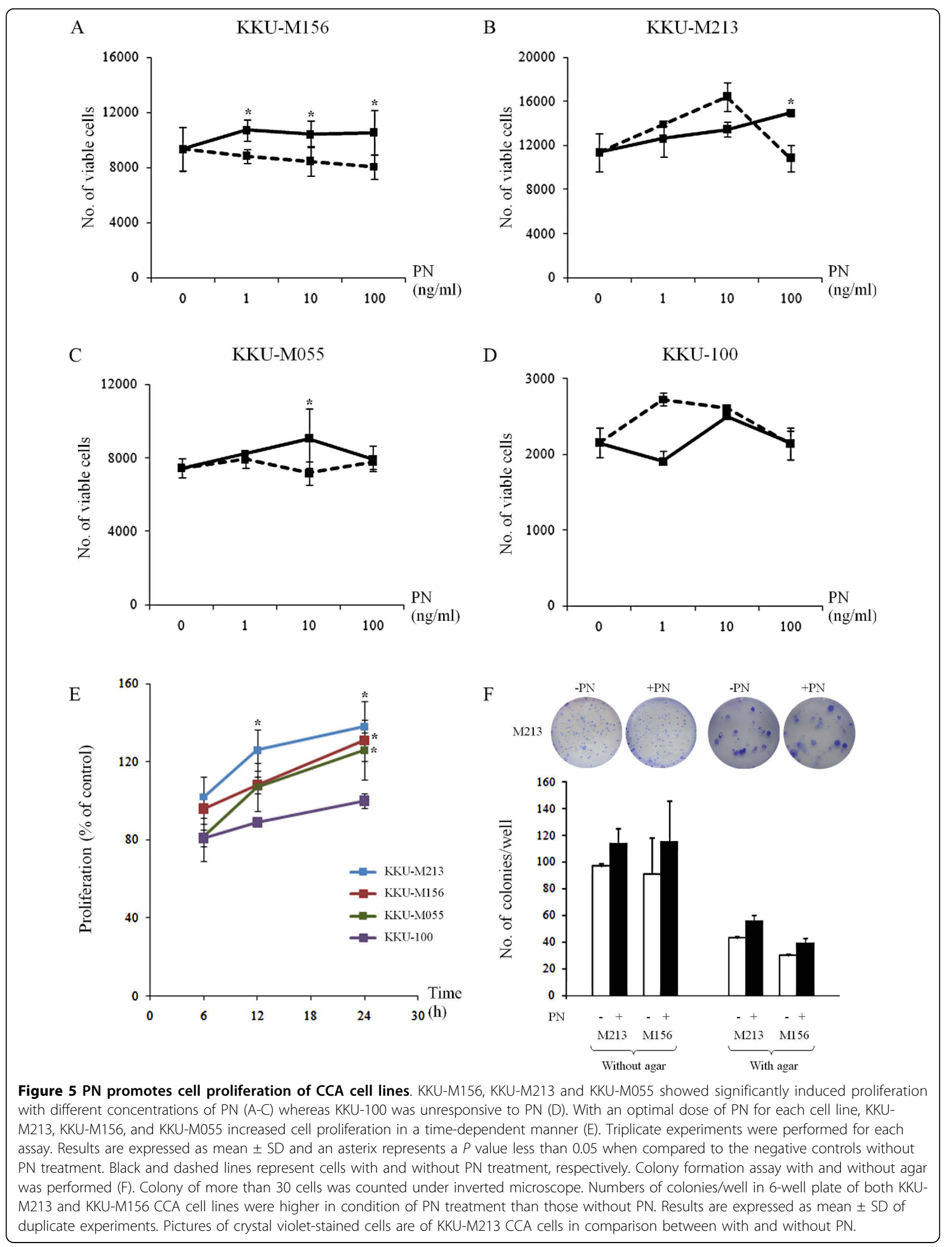


A

$$
\text { KKU-M213 }
$$

Control
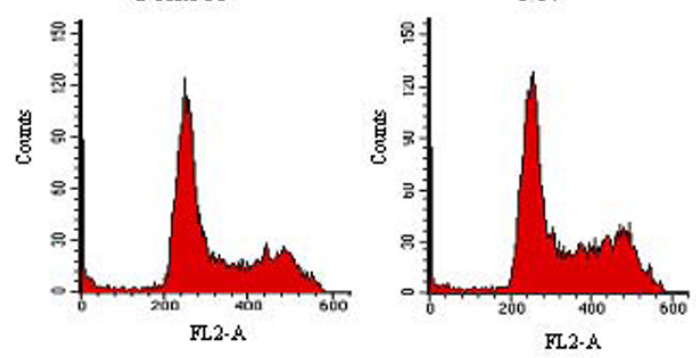

KKU-M156

Control

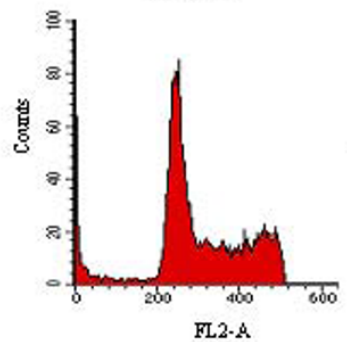

$+\mathrm{PN}$

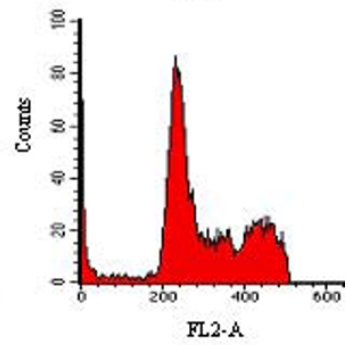

B

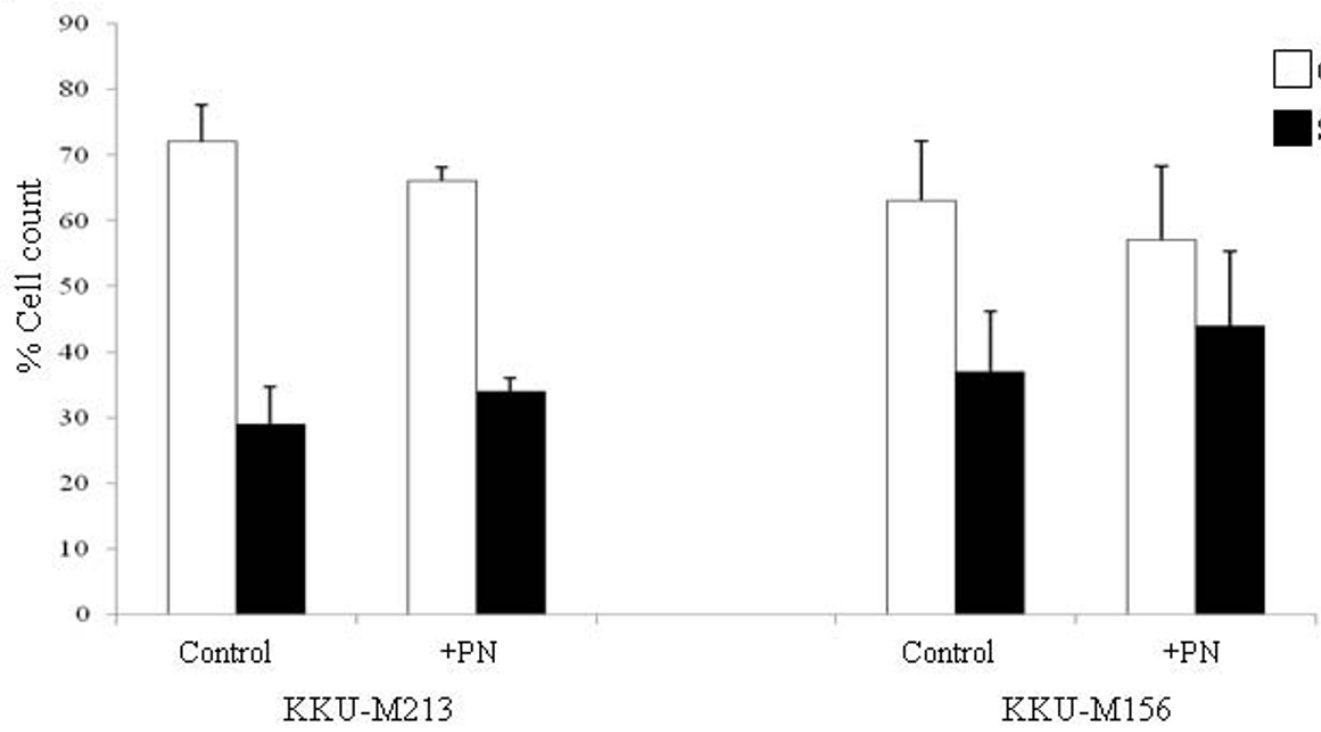

$\mathrm{C}$

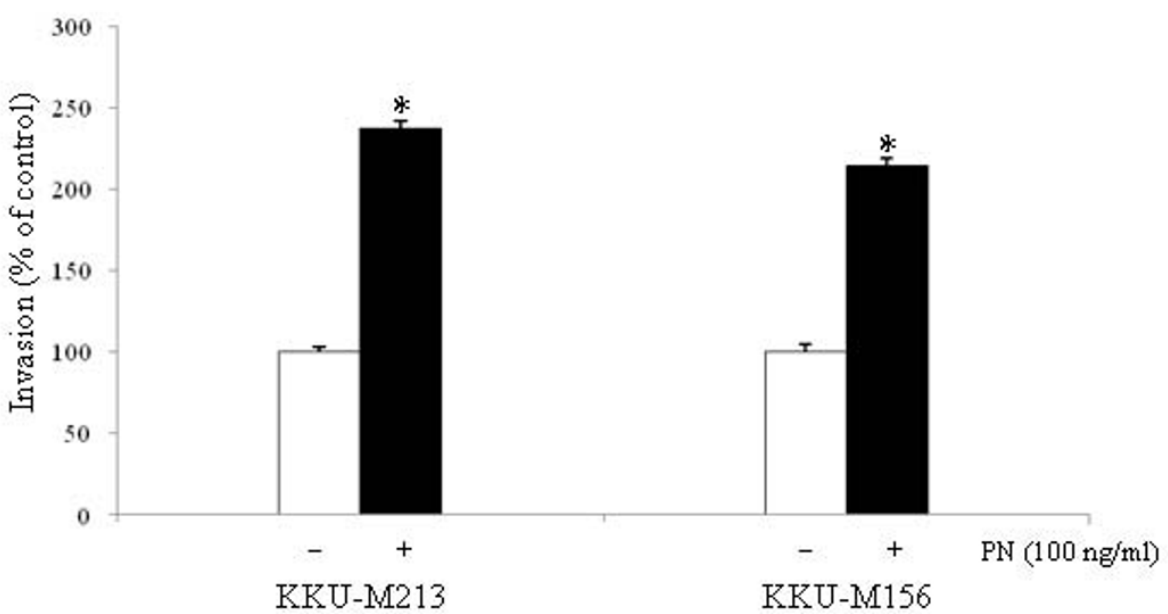

Figure 6 Cell cycle distribution and invasion analysis of cancer cells with and without stimulation by PN. Cell cycle analysis of KKU-M213 and KKU-M156 induced by PN (A). PN could drive cells from G1 into S and G2/M phases of the cell cycle when compared to control cells without PN treatment (B). Invasion induction by PN on KKU-M213 and KKU-M156 CCA cell lines is shown (C). Numbers of invaded cells when no PN was used served as control and were adjusted to be 100\% (white bar). The increase of invaded cells induced by PN is observed and shown by a black bar. Each bar graph represents mean \pm SD of three independent experiments. An asterix represents a $P$ value of less than 0.05 . 


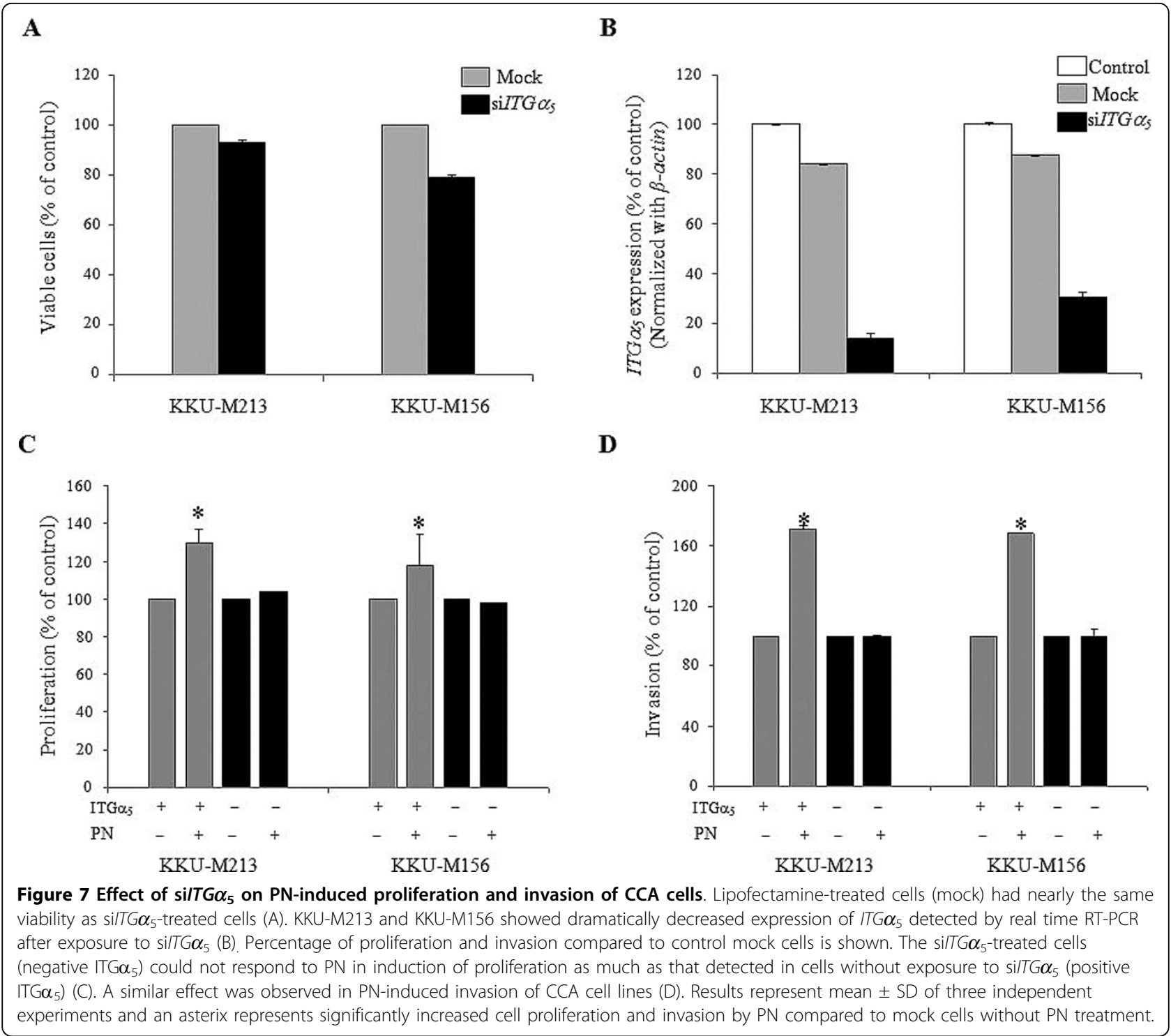

Theoretically, proteins secreted from fibroblasts having interplay with cancer cells could be detected in the extracellular region and be involved in ECM organization and biosynthesis. Within these 2 groups of genes, we focused our interest on genes encoded secreted proteins and their products have been previously reported of their tumorigenic effects. ADAM12, AREG, AGN2, ER, JAGL1, LAMA5, NOV, PDGF-A, PN, RL, and SCG2 were selected to explore. AREG, ER, JAGL1, and $L A M A 5$ are predominantly reported for proliferation induction in cancer cells [42-45]. PDGF-A, NOV, AGN2, and SCG2 are involved in angiogenesis [46-49], whereas $A D A M 12$ and $R L$ play an important role in cell motility, invasion and metastasis $[50,51]$. For $P N$, many carcinogenic functions including cell proliferation, invasion, metastasis and angiogenesis have been demonstrated
[20-24]. This study employed real time PCR to verify the up-regulation of these genes, and found that only ADAM12, AREG, ER, JAGL1, PDGF-A, PN and SCG2 were significantly increased in their expression levels in CCA-derived fibroblasts and may promote CCA progression through activation of cancer growth, invasion and angiogenesis.

Herein PN was chosen to deeply explore since its well accepted multifunction in cancer as mentioned above. Moreover, the result from our group about the expressions of ADAM12, AREG, ER, JAGL1, PDGF-A, PN and $S C G 2$ in whole CCA tissues $(\mathrm{n}=20)$ showed that only $A R E G, P D G F-A$ and $P N$ had higher level in cancer than those in benign liver tissues with statistical significance (data not shown). AREG and PDGF-A could be detected in not only fibroblasts but also in cancer and endothelial 
cells, however $P N$ expressed exclusively in CCA fibroblasts. In order to demonstrate role of fibroblast-derived proteins in CCA, we determined that $P N$ should be the first target to explore.

The strong evidence using different biological preparations of CCA-derived fibroblasts and CCA tissues confirmed the increased levels of PN at both mRNA and protein. Most of CCA tissues of all differentiated types had high levels of PN and expressed exclusively in $\alpha$ SMA positive fibroblasts. In the same direction, the findings showed no expression of PN in CCA cell lines when compared to the high level expressed in the fibroblasts. This may strengthen the results of the absence of PN in cancer cells in CCA tissues. From these results taken together, it can be concluded that PN detected in CCA tissues is only of fibroblast origin as reported in some cancers [52-54]. In cancers of head and neck, ovary, and colon, PN was found in cancer cells and has been proposed to induce tumorigenic properties of cancer cells via an autocrine mechanism $[21,22]$. Hence results from the present study allow the speculation to propose a phenomenon that fibroblast-derived PN in CCA may affect cancer cells by a paracrine mode and has a promising role in cancer promotion. These results revealed that a high PN level in fibroblasts was an independent risk factor in CCA patients and those having high PN had significantly low cumulative survival time after surgery. PN might therefore be used as a poor prognostic marker in patients suffering from CCA. Detections of PN at both mRNA and encoding protein in CCA tissues are in the same direction to distinguish CCA from non-cancer syndromes of bile ducts. In addition, most benign liver tissues and hepatocellular carcinoma showed no to only a minimal expression of $\mathrm{PN}$ when compared to the high level detected in CCA tissues. Hence, serum PN may help to distinguish CCA from benign conditions and closely-related liver cancer and may use as the prognostic or predictive marker as previously reported $[52,55]$.

To show the tumorigenic impacts of PN on CCA cells, recombinant $\mathrm{PN}$ was employed as extracellular $\mathrm{PN}$ to mimic the paracrine effect of PN produced from cancer stromal fibroblasts to induce CCA cell proliferation and invasion. Though receptors ITG $\alpha_{v} \beta_{3}$ and ITG $\alpha_{v} \beta_{5}$ have been shown to be the receptors for PN in several cancer cells [21], PN promoted invasiveness of pancreatic cancer cells via the $\beta_{4}$ integrin [56]. This suggests the cell type dependent on a specific ITG responded to PN. The study herein reveals that $\mathrm{PN}$-induced cell proliferation and invasion could be inhibited by RNAi against $I T G \alpha_{5}$. Hence, ITG $\alpha_{5}$ is a potentially promising receptor for PN in CCA cells. As the well known receptor for fibronectin, the apparent reason for ITG $\alpha_{5}$ production in CCA cells is to support the abundance of fibronectin found in CCA [57]. In addition, ITG $\alpha_{5}$ can only be from dimerization with the $\beta_{1}$ subunit and activation of ITG $\alpha_{5} \beta_{1}$ has been revealed to support cell survival [58] and induce invasion and angiogenesis $[59,60]$. Though further studies need to be performed before such a conclusion is valid in CCA, this work highlights the PNinduced-ITGa $\alpha_{5}$ pathway as one of the activated pathways to induce an aggressive CCA.

TGF- $\beta$ has been proposed to induce the expression of $P N$ [61]. O. viverrini excretory/secretory product has also recently been shown to be the stimulator of fibroblast proliferation via the TGF- $\beta$-mediated signal transduction pathway [62] and this pathway seems likely to be the cause of $P N$ expression in CCA-derived fibroblasts. The authors' laboratory has checked the effect of parasitic product-treated fibroblasts and found that these fibroblasts increased $P N$ expression compared to the normal liver fibroblasts without exposure (unpublished data). It is interesting to propose that in CCA cells; the expression of fibroblast-derived PN could be induced by TGF- $\beta$ produced from infected parasites since the early stage of carcinogenesis and may be in concert with TGF- $\beta$ produced from CCA cells in a late stage of cancer [12]. Though in vivo experiments are needed to confirm, fibroblast-derived PN may influence $O$. viverrini-associated CCA at the early stage of cancer as well as to promote cancer progression in the later time. With this information, targeting the stroma in CCA may not only be effective in treatment of primary, invasive and metastatic tumors, but may also play role in prevention of tumor development.

\section{Conclusions}

To the authors' knowledge, this study is the first to describe the gene expression profile of CCA-derived fibroblasts. Molecular understanding of fibroblasts in CCA by the functions of certain up- and down-regulated genes has been revealed and has suggested certain groups of genes in controlling cancer cell proliferation, invasion, metastasis and angiogenesis (Fig 8). These findings provide evidence that fibroblasts are important sources of tumorigenic substances, particularly PN, when produced into the microenvironment of CCA. High levels of PN are found in most CCA patients and can be used as a poor prognostic marker. In addition, the level of PN can be used to distinguish CCA from other benign liver conditions and hepatocellular carcinoma. The interaction of fibroblast-derived PN and CCA cells helps to promote cell proliferation and invasion probably via ITGa $\alpha_{5}$. Though further investigations are needed, this study suggests promising evidence of the value of using serum PN as a prognostic marker of poor survival in CCA patients. Moreover, targeting fibroblasts or fibroblast-derived-PN-stimulated pathways in cancer cells to attenuate the tumorigenic induction of $\mathrm{PN}$ is a further challenge to inhibit CCA progression in the patients. 


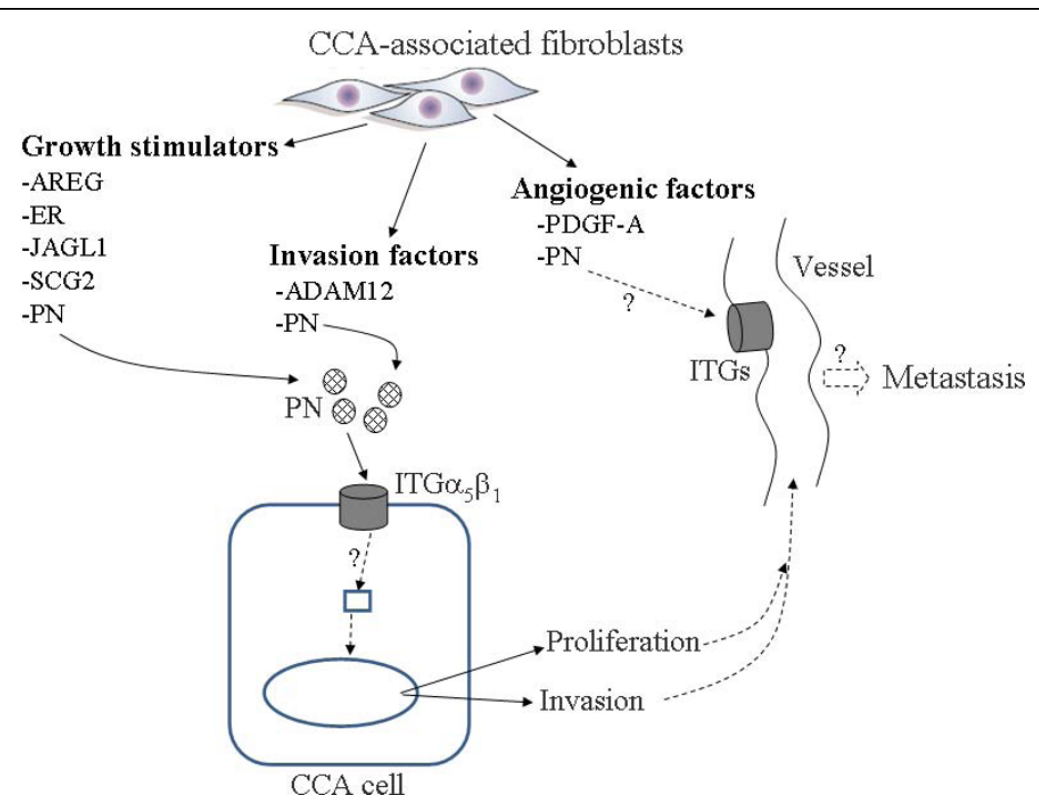

Figure 8 Proposed impacts of CCA-associated fibroblasts revealed in this study. A schematic representation of the main alterations in CCA-associated fibroblasts revealed in this study. The biological functions of protein products from the up-regulated genes in fibroblasts are represented. Tumorigenic effects of PN on CCA cancer cells are also proposed.

\section{Methods}

\section{Cells and culture condition}

Cfs and Lfs were established and characterized in this lab as previously reported [6]. CCA cell lines including KKU-M213; KKU-M156; KKU-M055; and KKU-100 were received as a kind gift from Associate Professor Dr. Banchob Sripa (Khon Kaen University). Cfs and Lfs were grown in the complete media which is $10 \%$ FBS containing DMEM with 20\% epidermal growth factor (CytoLab Ltd., Rehovot, Israel). CCA cells were cultured in 10\% FBS containing Ham-F12 (Invitrogen, Carlsbad, CA) supplemented with antibiotics and an anti-fungal agent at $37^{\circ} \mathrm{C}$ and in $5 \% \mathrm{CO}_{2}$ incubator.

\section{Gene expression profiling study and data analysis}

Total RNA was extracted using RNeasy Micro Kit (Qiagen, Valencia, CA) using the manufacturer's instructions. The quality of the RNA was assessed by an Agilent RNA 6000 Nano Kit (Agilent Technologies, Waldbronn, Germany). Affymetrix GeneChip Human Genome U133 plus 2.0 Array containing 38,500 human genes (Affymetrix, Santa Clara, CA) was used following Affymetrix's instruction. The array data were scanned by a GeneChip Scanner 3000 (Affymetrix) and analysed by Affymetrix microarray suite, version 5.0. Raw data from the GeneChips were used to analyze expression levels and expressed as fold changes and gene ontology was categorized by Gene Spring G.X.7.3 software (Agilent Technologies). Average fold change of gene expression was determined by intensity comparison between Cf and Lf1 and Lf2.

\section{Semi-quantitative real time PCR}

Complementary DNA was synthesized from $1 \mu \mathrm{g}$ of total RNA using the first strand cDNA synthesis kit (AMV) (Roche Molecular Biochemicals, Mannheim, Germany) according to the instructions. Relative expression levels in genes of Cfs and Lfs were determined by SYBR Green-based real time PCR using ABI 7500 (Applied Biosystem, Foster City, CA) and calculated by the $2^{-\Delta \Delta C}$ T equation. In this case, $\Delta C_{T}=C_{T}(C f)-C_{T}$ (Lf). $\beta$-actin served as an internal control to adjust the amount of starting cDNA. The sequences of genes tested in this study were retrieved from PubMed http:// www.ncbi.nlm.nih.gov and the primers were designed by Primer 3 (Table 7).

\section{Human CCA tissues and immunohistochemistry}

Fifty-two cases of CCA tissues were obtained from patients who had undergone hepatectomy using the protocol approved by the Human Research Ethics Committee, Khon Kaen University (HE490143). The age, sex, tumor size, histological type and staging data were derived from the medical charts and pathological records. Benign liver tissues were characterized as chronic inflammation by other causes rather than CCA.

Paraffin-embedded tissues were used and antigens were retrieved in $10 \mathrm{mM}$ citrate buffer $\mathrm{pH} 6.0$ at $95^{\circ} \mathrm{C}$ for $40 \mathrm{~min}$ and endogenous peroxidase was blocked in $3 \% \mathrm{H}_{2} \mathrm{O}_{2}$ for $5 \mathrm{~min}$. After blocking non-specific binding with $2 \%$ bovine serum albumin for $20 \mathrm{~min}, 1: 10,000 \mathrm{rab}-$ bit anti-human PN (Biovendor, Heidelberg, Germany) 
Table 7 Primer sequences for real time PCR.

\begin{tabular}{lllll}
\hline Gene & $\begin{array}{l}\text { Forward Primer } \\
\mathbf{5}^{\prime} \mathbf{3}^{\prime}\end{array}$ & $\begin{array}{l}\text { Reverse Primer } \\
\mathbf{5}^{\prime}-\mathbf{3}^{\prime}\end{array}$ & $\begin{array}{l}\text { Size } \\
\mathbf{( b p )}\end{array}$ & Accession no. \\
\hline ADAM12 & tttgggggtcaacagtttc & agagctgggttccctttgt & 191 & NM_003474 \\
AREG & tggggaaaagtccatgaaaa & tttcgttcctcagcttctcc & 174 & NM_001657 \\
AGN2 & ccacctgaggaactgtctcg & ggtcttgctttggtccgtta & 191 & NM_001147 \\
$E R$ & catatgggagaagggggagt & aagtgcaattacagagtgcaaaa & 166 & NM_001432 \\
JAGL1 & gcctgccttaagtgaggaaa & gccaagaacaacacatcaaaga & 169 & U77914 \\
LAMA5 & gtgatgaaaagcgggaatgt & acctccacagagcgagtcat & 221 & BC003355 \\
NOV & tgcaattccaagaaaatatcactg & cttggatttggagcttggaa & 167 & NM_002514 \\
$P D G F-A$ & acacgagcagtgtcaagtgc & tctggttggctgctttaggt & 250 & X03795 \\
$P N$ & cactcttgctcccaccaat & tcaaagactgctcctcccata & 157 & AY140646 \\
$R L$ & tgctgaatttggggctactt & gggagatagggtcttcatcca & 198 & NM_005045 \\
SCG2 & cccgaagaatgatgataccc & aaatgttgggatttgcttgg & 195 & NM_003469 \\
ITG $\boldsymbol{\alpha}_{5}$ & agttgcatttccgagtctgg & ccaaacaggatggctaggat & 223 & NM_002205 \\
$\beta$ - $a c t i n$ & cacactgtgcccatctacga & ctccttaatgtcacgcacga & 162 & X00351 \\
gapdh & ctcctcctgttcgacagtca & gttaaaagcagccctggtga & 140 & NM_002046 \\
\hline
\end{tabular}

Note: ADAM12, a disintegrin and matrix metalloproteinase 12; AREG, amphiregulin; AGN2, angiopoietin 2; ER, epiregulin; JAGL1, jagged soluble form; LAMA5, laminin alpha 5; NOV, nephroblastoma over expressed; $P D G F-A$, platelet-derived growth factor alpha; $P N$, periostin; $R L$, reelin; SCG2, secretogranin 2; ITG $\alpha 5$, integrin alpha $5 ; \beta$-actin, beta-actin; gapdh, glyceraldehyde 3-phosphate dehydrogenase

was applied to the sections at room temperature overnight, followed by anti-rabbit Envision ${ }^{+}$System-HRP labeled polymer (Dako, Carpinteria, CA) for $30 \mathrm{~min}$ at room temperature. The immunoreactive signal was developed by diaminobenzidine (DAB; Sigma, St Louis, $\mathrm{MO})$ and counterstained with hematoxylin. The signal was checked under light microscope.

PN expression of intratumoral fibroblasts on the histologic sections was semi-quantitatively scored on the basis of PN-positive fibroblasts percentage and the immunostaining intensity. The number of positive fibroblast cells were classified as < 10\% (negative); $10-25 \%(+1) ; 26-50 \%$ $(+2)$; and $>50 \%(+3)$. The intensity of PN expression in fibroblasts was scored no staining, 0; weak staining, 1; intermediate or focal weak and focal intense staining, 2; intense staining, 3. The interpretation of PN expression was performed by summarization the scores of the percent positive cell (0-3) and the scores of staining intensity (1-3) to reach the total final score of 0-6. The results were then categorized as follows; low expression, score $\leq$ 4 ; and high expression, score $>4$. All samples were anonymized and independently scored by one pathologist (KC) and 2 investigators (PT and CT). In case of disagreement, the slides were reexamined and a consensus was reached by at least 2 observers.

\section{Double immunofluorescence staining of $\alpha$-SMA and PN}

In order to localize the expression of PN and $\alpha$-SMA in CCA tissues, double immunofluorescence staining was performed. The 1:200 mouse anti-human $\alpha$-SMA antibody (Sigma) and 1:500 rabbit anti-human PN antibody (Biovendor) were used as primary antibodies. Anti-mouse IgG-Alexa 488 and anti-rabbit IgG-Cy3 (Invitrogen) were used as the second antibodies. Nucleus was stained with Hoechst (Invitrogen). The signal was observed under the LSM 510 Meta laser scanning confocal microscope (Carl Zeiss, Jena, Germany) at the Division of Medical Molecular Biology, Office for Research and Development, Faculty of Medicine Siriraj Hospital, Mahidol University.

\section{Protein extraction and western blot analysis}

Twenty $\mu$ gs of total protein from the cell lysate were separated in $10 \%$ SDS-PAGE and transferred onto a PVDF membrane (Millipore, Billerica, MA). For PN detection, 1:500 rabbit anti-human PN (Biovendor) and 1:1,000 goat anti-rabbit conjugated HRP (Abcam, Cambridge, MA) were used. The signal was visualized by ECL (Pierce, Rockford, IL). The expression of $\beta$-actin was used as an internal control to determine an equal amount of loading proteins.

\section{Cell proliferation assay}

CCA cells with or without treatment with si $I T G \alpha_{5}$ cells were arrested in HAM-F12 without serum supplement for $12 \mathrm{~h}$. Different concentrations of recombinant PN (Biovendor) prepared in 1\% FBS containing HAM-F12 were incubated with cells for 6,12 and $24 \mathrm{~h}$. The viable cells in each condition were determined using an MTS assay (Promega, Madison, WI) according to the manufacturer's instruction.

\section{Cell cycle analysis by flow cytometry}

Cell cycle distribution analysis used cells stained with propidium iodide (Invitrogen) as previously described [63]. The distribution of cells in each stage of the cell cycle was quantitated in a flow cytometer and CellQuest software (Becton Dickinson, Franklin Lakes, NJ). 
Numbers of CCA cell lines in $\mathrm{S}+\mathrm{G} 2 / \mathrm{M}$ phases of the cell cycle were measured and compared between conditions with and without recombinant PN treatment. These experiments were repeated two times using replicate culture dishes in the same experiment.

\section{Colony formation assay}

CCA cell lines were cultured in 6-well plate. After 24-h culture, recombinant PN diluted in 1\% FBS containing medium was added and the plate was incubated in $\mathrm{CO}_{2}$ incubator. Soft agar colony formation assay was also performed using $0.5 \%$ and $0.35 \%$ MetaPhor $^{\bullet}$ agarose (Cambrex Bio Science, Rockland, ME) as lower and upper layers, respectively. After $12 \mathrm{~d}$, cells were fixed with $5 \% \mathrm{v} / \mathrm{v}$ glutaraldehyde and stained with $0.5 \% \mathrm{w} / \mathrm{v}$ crystal violet in $40 \% \mathrm{v} / \mathrm{v}$ methanol. Cell growth was estimated by counting numbers of colonies with more than 30 cells under inverted microscope and compared between those of treat and untreated with PN. The experiment was performed in duplicate.

\section{Invasion assay}

KKU-M213 and KKU-M156 CCA cells were seeded in PN $(100 \mathrm{ng} / \mathrm{ml})$ containing medium into the Matrigel invasion chamber (BD Biosciences, San Jose, CA) and incubated for $24 \mathrm{~h}$. Invaded cells were fixed with $5 \% \mathrm{v} / \mathrm{v}$ glutaraldehyde and stained with $0.5 \% \mathrm{w} / \mathrm{v}$ crystal violet in $40 \% \mathrm{v} / \mathrm{v}$ methanol for $30 \mathrm{~min}$ each. The number of invaded cells was counted under a microscope by two independent investigators using $100 \times$ magnification fields. The assays were done in replicate and three independent experiments were performed.

\section{Small interfering RNA against receptor integrin $\alpha_{5}$}

Two hundred thousand CCA cells were seeded into a 6well plate for $24 \mathrm{~h}$ before transfection of si $I T G \alpha_{5}$ (Santa Cruz Biotechnology, Santa Cruz, CA) by Lipofectamine 2000 (Invitrogen). Three siRNA strands (5'-gucagaauuucgagacaaa-3', 5'-caccaacaagagagccaaa-3', and 5'ccacugaccagaacuagaa- $3^{\prime}$ ) were used to target ITG $\alpha_{5}$ mRNA. The efficiency of knock down was tested by real time PCR using $\beta$-actin as an internal control.

\section{Statistical analysis}

Statistical analyses were performed using SPSS version 16.0 (SPSS Inc., Chicago, IL). The correlation of PN expression and pathological parameters of CCA patients was analyzed by the $\chi^{2}$-test and binary logistic multivariate analysis. Patient survival was calculated from the time of surgical resection to death and the survival curves were constructed according to KaplanMeier, with a Log-Rank test. A multivariate analysis was performed by the Cox proportional hazard regression model. The significance of the different data was determined by the Student's t-test. A $P$ value of equal to or less than 0.05 was defined as statistically significant.

\section{Acknowledgements}

We would like to thank the Commission on Higher Education, Thailand for supporting by grant fund under the program Strategic Scholarships for Frontier Research Network for the Ph.D. Program Thai Doctoral degree for this research. This project was co-supported by a Mid-Career Grant (RMU5080069), Thailand Research Fund (TRF) and the Research Strengthening Grant 2007 from National Center for Genetic Engineering and Biotechnology (BIOTEC), National Science and Technology Development Agency (NSTDA). The English editing of this manuscript was kindly performed by Professor James A. Will, University of Wisconsin, Madison, WI, USA.

\section{Author details}

${ }^{1}$ Department of Biochemistry, Faculty of Medicine, Khon Kaen University, 123 Mitraparb Road, Muang, Khon Kaen 40002, Thailand. ²Department of Immunology, Faculty of Medicine Siriraj Hospital, Mahidol University, 2 Prannok Road, Bangkok Noi, Bangkok 10700, Thailand. ${ }^{3}$ Department of Biochemistry and Molecular Biology, Nihon University School of Dentistry at Matsudo, Matsudo, Chiba 2718587, Japan. ${ }^{4}$ Department of Pathology, Faculty of Medicine Siriraj Hospital, Mahidol University, Thailand. ${ }^{5}$ Department of Pathology, Faculty of Medicine, Khon Kaen University, Thailand. ${ }^{6}$ Department of Surgery, Faculty of Medicine, Khon Kaen University, Thailand. ' $L i v e r$ Fluke and Cholangiocarcinoma Research Center, Faculty of Medicine, Khon Kaen University, Thailand.

\section{Authors' contributions}

$\mathrm{KU}$ performed most of the experiments and helped to draft the manuscript. YA contributed to the microarray experiment. PT performed real time PCR of some genes and helped KC and AP in immunohistochemical scoring. SC contributed to the patient clinicopathological data and samples collection. $C T$ contributed to the design of the entire study, data analysis and preparation of the manuscript.

All authors have read and approved the final manuscript.

\section{Competing interests}

The authors declare that they have no competing interests.

\section{Received: 8 September 2009}

Accepted: 24 January 2010 Published: 24 January 2010

\section{References}

1. Sriamporn S, Pisani P, Pipitgool V, Suwanrungruang K, Kamsa-ard S, Parkin DM: Prevalence of Opisthorchis viverrini infection and incidence of cholangiocarcinoma in Khon Kaen, Northeast Thailand. Trop Med Int Health 2004, 9:588-594.

2. Lim MK, Ju YH, Franceschi S, Oh JK, Kong HJ, Hwang SS, Park SK, Cho SI, Sohn WM, Kim DI, Yoo KY, Hong ST, Shin HR: Clonorchis sinensis infection and increasing risk of cholangiocarcinoma in the Republic of Korea. Am J Trop Med Hyg 2006, 75:93-96.

3. Choi D, Lim JH, Lee KT, Lee JK, Choi SH, Heo JS, Jang KT, Lee NY, Kim S, Hong ST: Cholangiocarcinoma and Clonorchis sinensis infection: a casecontrol study in Korea. J Hepatol 2006, 44:1066-1073.

4. Lazaridis KN, Gores GJ: Primary sclerosing cholangitis and cholangiocarcinoma. Semin Liver Dis 2006, 26:42-51.

5. Okamura N, Yoshida M, Shibuya A, Sugiura H, Okayasu I, Ohbu M: Cellular and stromal characteristics in the scirrhous hepatocellular carcinoma: comparison with hepatocellular carcinomas and intrahepatic cholangiocarcinomas. Pathol Int 2005, 55:724-731.

6. Chuaysri C, Thuwajit P, Paupairoj A, Chau-In S, Suthiphongchai T, Thuwajit C: Alpha-smooth muscle actin-positive fibroblasts promote biliary cell proliferation and correlate with poor survival in cholangiocarcinoma. Oncol Rep 2009, 21:957-969.

7. Hwang RF, Moore T, Arumugam T, Ramachandran V, Amos KD, Rivera A, Ji B, Evans DB, Logsdon CD: Cancer-associated stromal fibroblasts promote pancreatic tumor progression. Cancer Res 2008, 68:918-926. 
8. Micke P, Ostman A: Exploring the tumour environment: cancer-associated fibroblasts as targets in cancer therapy. Expert Opin Ther Targets 2005, 9:1217-1233.

9. Augsten M, Hagglof C, Olsson E, Stolz C, Tsagozis P, Levchenko T, Frederick MJ, Borg A, Micke P, Egevad L, Ostman A: CXCL14 is an autocrine growth factor for fibroblasts and acts as a multi-modal stimulator of prostate tumor growth. Proc Natl Acad Sci USA 2009, 106:3414-3419.

10. Tuxhorn JA, Ayala GE, Rowley DR: Reactive stroma in prostate cancer progression. J Urol 2001, 166:2472-2483.

11. Rosenthal EL, McCrory A, Talbert M, Carroll W, Magnuson JS, Peters GE: Expression of proteolytic enzymes in head and neck cancer-associated fibroblasts. Arch Otolaryngol Head Neck Surg 2004, 130:943-947.

12. Ohira S, Itatsu K, Sasaki M, Harada K, Sato Y, Zen Y, Ishikawa A, Oda K, Nagasaka T, Nimura $Y$, Nakanuma $Y$ : Local balance of transforming growth factor-beta1 secreted from cholangiocarcinoma cells and stromalderived factor-1 secreted from stromal fibroblasts is a factor involved in invasion of cholangiocarcinoma. Pathol Int 2006, 56:381-389.

13. Singer CF, Gschwantler-Kaulich D, Fink-Retter A, Haas C, Hudelist G, Czerwenka K, Kubista E: Differential gene expression profile in breast cancerderived stromal fibroblasts. Breast Cancer Res Treat 2008, 110:273-281.

14. Micke P, Kappert K, Ohshima M, Sundquist C, Scheidl S, Lindahl P, Heldin $\mathrm{CH}$, Botling J, Ponten F, Ostman A: In situ identification of genes regulated specifically in fibroblasts of human basal cell carcinoma. J Invest Dermatol 2007, 127:1516-1523.

15. Fromigue O, Louis K, Dayem M, Milanini J, Pages G, Tartare-Deckert S, Ponzio G, Hofman P, Barbry P, Auberger P, Mari B: Gene expression profiling of normal human pulmonary fibroblasts following coculture with non-small-cell lung cancer cells reveals alterations related to matrix degradation, angiogenesis, cell growth and survival. Oncogene 2003, 22:8487-8497.

16. Allinen $M$, Beroukhim $R$, Cai $L$, Brennan C, Lahti-Domenici J, Huang $H$, Porter D, Hu M, Chin L, Richardson A, Schnitt S, Sellers WR, Polyak K: Molecular characterization of the tumor microenvironment in breast cancer. Cancer Cell 2004, 6:17-32.

17. Fukushima N, Sato N, Prasad N, Leach SD, Hruban RH, Goggins M: Characterization of gene expression in mucinous cystic neoplasms of the pancreas using oligonucleotide microarrays. Oncogene 2004, 23:9042-9051.

18. Nakagawa H, Liyanarachchi S, Davuluri RV, Auer H, Martin EW Jr, de la Chapelle A, Frankel WL: Role of cancer-associated stromal fibroblasts in metastatic colon cancer to the liver and their expression profiles. Oncogene 2004, 23:7366-7377.

19. Erkan M, Kleeff J, Gorbachevski A, Reiser C, Mitkus T, Esposito I, Giese T, Buchler MW, Giese NA, Friess H: Periostin creates a tumor-supportive microenvironment in the pancreas by sustaining fibrogenic stellate cell activity. Gastroenterology 2007, 132:1447-1464.

20. Tai IT, Dai M, Chen LB: Periostin induction in tumor cell line explants and inhibition of in vitro cell growth by anti-periostin antibodies. Carcinogenesis 2005, 26:908-915.

21. Gillan L, Matei D, Fishman DA, Gerbin CS, Karlan BY, Chang DD: Periostin secreted by epithelial ovarian carcinoma is a ligand for alpha(V)beta(3) and alpha(V)beta(5) integrins and promotes cell motility. Cancer Res 2002, 62:5358-5364.

22. Kudo Y, Ogawa I, Kitajima S, Kitagawa M, Kawai H, Gaffney PM, Miyauchi M, Takata T: Periostin promotes invasion and anchorage-independent growth in the metastatic process of head and neck cancer. Cancer Res 2006, 66:6928-6935.

23. Siriwardena BS, Kudo Y, Ogawa I, Kitagawa M, Kitajima S, Hatano H, Tilakaratne WM, Miyauchi M, Takata T: Periostin is frequently overexpressed and enhances invasion and angiogenesis in oral cancer. Br J Cancer 2006, 95:1396-1403.

24. Shao R, Bao S, Bai X, Blanchette C, Anderson RM, Dang T, Gishizky ML, Marks JR, Wang XF: Acquired expression of periostin by human breast cancers promotes tumor angiogenesis through up-regulation of vascular endothelial growth factor receptor 2 expression. Mol Cell Biol 2004, 24:3992-4003.

25. De Wever O, Demetter P, Mareel M, Bracke M: Stromal myofibroblasts are drivers of invasive cancer growth. Int J Cancer 2008, 123:2229-2238.

26. Howell OW, Scharfman HE, Herzog H, Sundstrom LE, Beck-Sickinger A, Gray WP: Neuropeptide $Y$ is neuroproliferative for post-natal hippocampal precursor cells. J Neurochem 2003, 86:646-659.
27. Burgess HA, Reiner O: Doublecortin-like kinase is associated with microtubules in neuronal growth cones. Mol Cell Neurosci 2000, 16:529-541.

28. Aycock RL, Bradshaw AC, Sage EH, Starcher B: Development of UV-induced squamous cell carcinomas is suppressed in the absence of SPARC. J Invest Dermatol 2004, 123:592-599.

29. Croucher DR, Saunders DN, Lobov S, Ranson M: Revisiting the biological roles of PAI2 (SERPINB2) in cancer. Nat Rev Cancer 2008, 8:535-545.

30. Duggan C, Kennedy S, Kramer MD, Barnes C, Elvin P, McDermott E, O'Higgins N, Duffy MJ: Plasminogen activator inhibitor type 2 in breast cancer. Br J Cancer 1997, 76:622-627.

31. Osmak M, Babic D, Abramic M, Milicic D, Vrhovec I, Skrk J: Plasminogen activator inhibitor type 2: potential prognostic factor for endometrial carcinomas. Neoplasma 2001, 48:462-467.

32. Schmidt-Hansen B, Klingelhofer J, Grum-Schwensen B, Christensen A, Andresen S, Kruse C, Hansen T, Ambartsumian N, Lukanidin E, Grigorian M: Functional significance of metastasis-inducing S100A4(Mts1) in tumorstroma interplay. J Biol Chem 2004, 279:24498-24504.

33. Steiglitz BM, Keene DR, Greenspan DS: PCOLCE2 encodes a functional procollagen C-proteinase enhancer (PCPE2) that is a collagen-binding protein differing in distribution of expression and post-translational modification from the previously described PCPE1. J Biol Chem 2002, 277:49820-49830.

34. Tomari K, Kumagai T, Shimizu T, Takeda K: Bone morphogenetic protein-2 induces hypophosphorylation of $\mathrm{Rb}$ protein and repression of $\mathrm{E} 2 \mathrm{~F}$ in androgen-treated LNCaP human prostate cancer cells. Int J Mol Med 2005, 15:253-258.

35. Zheng M, Bocangel D, Ramesh R, Ekmekcioglu S, Poindexter N, Grimm EA, Chada S: Interleukin-24 overcomes temozolomide resistance and enhances cell death by down-regulation of 06-methylguanine-DNA methyltransferase in human melanoma cells. Mol Cancer Ther 2008, 7:3842-3851.

36. Zou J, Ren JH, Feng D, Wang $H, X u J$ : Compensatory function of bradykinin B1 receptor in the inhibitory effect of captopril on cardiomyocyte hypertrophy and cardiac fibroblast proliferation in neonatal rats. Chin Med J (Engl) 2008, 121:1220-1225.

37. Saigusa K, Imoto I, Tanikawa C, Aoyagi M, Ohno K, Nakamura Y, Inazawa J: RGC32, a novel p53-inducible gene, is located on centrosomes during mitosis and results in G2/M arrest. Oncogene 2007, 26:1110-1121.

38. Mueller MM, Fusenig NE: Friends or foes - bipolar effects of the tumour stroma in cancer. Nat Rev Cancer 2004, 4:839-849.

39. Hirohata S, Wang LW, Miyagi M, Yan L, Seldin MF, Keene DR, Crabb JW Apte SS: Punctin, a novel ADAMTS-like molecule, ADAMTSL-1, in extracellular matrix. J Biol Chem 2002, 277:12182-12189.

40. Vazquez F, Hastings G, Ortega MA, Lane TF, Oikemus S, Lombardo M, IruelaArispe ML: METH-1, a human ortholog of ADAMTS-1, and METH-2 are members of a new family of proteins with angio-inhibitory activity. J Biol Chem 1999, 274:23349-23357.

41. Luque A, Carpizo DR, Iruela-Arispe ML: ADAMTS1/METH1 inhibits endothelial cell proliferation by direct binding and sequestration of VEGF165. J Biol Chem 2003, 278:23656-23665.

42. Castillo J, Erroba E, Perugorria MJ, Santamaria M, Lee DC, Prieto J, Avila MA, Berasain C: Amphiregulin contributes to the transformed phenotype of human hepatocellular carcinoma cells. Cancer Res 2006, 66:6129-6138.

43. Morita S, Shirakata Y, Shiraishi A, Kadota Y, Hashimoto K, Higashiyama S, Ohashi Y: Human corneal epithelial cell proliferation by epiregulin and its cross-induction by other EGF family members. Mol Vis 2007, 13:2119-2128

44. Purow BW, Haque RM, Noel MW, Su Q, Burdick MJ, Lee J, Sundaresan T, Pastorino S, Park JK, Mikolaenko I, Maric D, Eberhart CG, Fine HA: Expression of Notch-1 and its ligands, Delta-like-1 and Jagged-1, is critical for glioma cell survival and proliferation. Cancer Res 2005, 65:2353-2363.

45. Gonzales M, Haan K, Baker SE, Fitchmun M, Todorov I, Weitzman S, Jones JC: A cell signal pathway involving laminin-5, alpha3beta1 integrin, and mitogen-activated protein kinase can regulate epithelial cell proliferation. Mol Biol Cell 1999, 10:259-270.

46. Shikada $Y$, Yonemitsu $Y$, Koga T, Onimaru M, Nakano T, Okano S, Sata S, Nakagawa K, Yoshino I, Maehara Y, Sueishi K: Platelet-derived growth factor-AA is an essential and autocrine regulator of vascular endothelial growth factor expression in non-small cell lung carcinomas. Cancer Res 2005, 65:7241-7248. 
47. Lin CG, Leu SJ, Chen N, Tebeau CM, Lin SX, Yeung CY, Lau LF: CCN3 (NOV) is a novel angiogenic regulator of the CCN protein family. J Biol Chem 2003, 278:24200-24208.

48. Lobov IB, Brooks PC, Lang RA: Angiopoietin-2 displays VEGF-dependent modulation of capillary structure and endothelial cell survival in vivo. Proc Natl Acad Sci USA 2002, 99:11205-11210.

49. Kirchmair R, Gander R, Egger M, Hanley A, Silver M, Ritsch A, Murayama T, Kaneider N, Sturm W, Kearny M, Fischer-Colbrie R, Kircher B, Gaenzer H, Wiedermann CJ, Ropper AH, Losordo DW, Patsch JR, Schratzberger P: The neuropeptide secretoneurin acts as a direct angiogenic cytokine in vitro and in vivo. Circulation 2004, 109:777-783.

50. Le Pabic H, Bonnier D, Wewer UM, Coutand A, Musso O, Baffet G, Clement B, Theret N: ADAM12 in human liver cancers: TGF-betaregulated expression in stellate cells is associated with matrix remodeling. Hepatology 2003, 37:1056-1066.

51. Hashimoto-Torii K, Torii M, Sarkisian MR, Bartley CM, Shen J, Radtke F, Gridley T, Sestan N, Rakic P: Interaction between reelin and notch signaling regulates neuronal migration in the cerebral cortex. Neuron 2008, 60:273-284.

52. Sasaki H, Dai M, Auclair D, Fukai I, Kiriyama M, Yamakawa Y, Fujii Y, Chen LB: Serum level of the periostin, a homologue of an insect cell adhesion molecule, as a prognostic marker in nonsmall cell lung carcinomas. Cancer 2001, 92:843-848.

53. Fukushima N, Kikuchi Y, Nishiyama T, Kudo A, Fukayama M: Periostin deposition in the stroma of invasive and intraductal neoplasms of the pancreas. Mod Pathol 2008, 21:1044-1053.

54. Kikuchi Y, Kashima TG, Nishiyama T, Shimazu K, Morishita Y, Shimazaki M, Kii I, Horie H, Nagai H, Kudo A, Fukayama M: Periostin is expressed in pericryptal fibroblasts and cancer-associated fibroblasts in the colon. $J$ Histochem Cytochem 2008, 56:753-764.

55. Sasaki H, Yu CY, Dai M, Tam C, Loda M, Auclair D, Chen LB, Elias A: Elevated serum periostin levels in patients with bone metastases from breast but not lung cancer. Breast Cancer Res Treat 2003, 77:245-252.

56. Baril P, Gangeswaran R, Mahon PC, Caulee K, Kocher HM, Harada T, Zhu M, Kalthoff H, Crnogorac-Jurcevic T, Lemoine NR: Periostin promotes invasiveness and resistance of pancreatic cancer cells to hypoxiainduced cell death: role of the beta4 integrin and the PI3k pathway. Oncogene 2007, 26:2082-2094.

57. Chen CY, Lin XZ, Tsao HC, Shiesh SC: The value of biliary fibronectin for diagnosis of cholangiocarcinoma. Hepatogastroenterology 2003, 50:924-927.

58. Zhang Z, Vuori K, Reed JC, Ruoslahti E: The alpha 5 beta 1 integrin supports survival of cells on fibronectin and up-regulates $\mathrm{BCl}-2$ expression. Proc Natl Acad Sci USA 1995, 92:6161-6165.

59. Zeng ZZ, Yao H, Staszewski ED, Rockwood KF, Markwart SM, Fay KS, Spalding AC, Livant DL: Alpha(5)beta(1) integrin ligand PHSRN induces invasion and alpha(5) mRNA in endothelial cells to stimulate angiogenesis. Transl Oncol 2009, 2:8-20

60. Tuomi S, Mai A, Nevo J, Laine JO, Vilkki V, Ohman TJ, Gahmberg CG Parker PJ, Ivaska J: PKCepsilon regulation of an alpha5 integrin-ZO-1 complex controls lamellae formation in migrating cancer cells. Sci Signal 2009, 2:ra32.

61. Horiuchi K, Amizuka N, Takeshita S, Takamatsu H, Katsuura M, Ozawa H, Toyama Y, Bonewald LF, Kudo A: Identification and characterization of a novel protein, periostin, with restricted expression to periosteum and periodontal ligament and increased expression by transforming growth factor beta. J Bone Miner Res 1999, 14:1239-1249.

62. Thuwajit C, Thuwajit $P$, Uchida K, Daorueang D, Kaewkes S, Wongkham S, Miwa M: Gene expression profiling defined pathways correlated with fibroblast cell proliferation induced by Opisthorchis viverrini excretory/ secretory product. World J Gastroenterol 2006, 12:3585-3592.

63. Thuwajit C, Thuwajit P, Kaewkes S, Sripa B, Uchida K, Miwa M, Wongkham S: Increased cell proliferation of mouse fibroblast $\mathrm{NIH}-3 \mathrm{~T} 3$ in vitro induced by excretory/secretory product(s) from Opisthorchis viverrini. Parasitology 2004, 129:455-464.

doi:10.1186/1476-4598-9-13

Cite this article as: Utispan et al:: Gene expression profiling of cholangiocarcinoma-derived fibroblast reveals alterations related to tumor progression and indicates periostin as a poor prognostic marker. Molecular Cancer 2010 9:13.

\section{Submit your next manuscript to BioMed Central and take full advantage of:}

- Convenient online submission

- Thorough peer review

- No space constraints or color figure charges

- Immediate publication on acceptance

- Inclusion in PubMed, CAS, Scopus and Google Scholar

- Research which is freely available for redistribution 